\title{
Developing local currency bond markets for long-term development financing in Sub-Saharan Africa
}

\author{
Kathrin Berensmann* \\ Florence Dafe** \\ Ulrich Volz****
}

This article discusses the role that local currency bond markets (LCBMs) can play in the longterm financing of sustainable development of Sub-Saharan African (SSA) economies, and presents an empirical analysis of the factors which may hinder or promote the development of such markets in SSA. Using a new dataset for 27 SSA countries, our findings support earlier research on SSA and other regions, showing that LCBM development is related to country size, larger banking systems, greater trade openness and better regulatory frameworks, and the rule of law. Foreign investor participation broadens the investor base and can give a boost to LCBM development, yet it may also increase volatility of international capital flows. Hence, with a view to the experience of emerging economies in other regions, capital market liberalization should be pursued only very cautiously and in step with solid financial and institutional development.

Keywords: Local currency bond markets; long-term finance; debt; Sub-Saharan Africa. JEL classification: F21, F34, G23, H63, O11.

\footnotetext{
* German Development Institute, e-mail: kathrin.berensmann@die-gdi.de

** German Development Institute and Institute of Development Studies, University of Sussex, email: florence.dafe@die-gdi.de

*** SOAS, University of London, and German Development Institute, e-mail: uv1@ soas.ac.uk

We are grateful for comments and suggestions received from participants at the IMF/CFD Conference on Financing for Development held at the Graduate Institute in Geneva on 15-16 April 2015. We especially thank our discussant, David Vines, as well as Christopher Adam, Andrea Presbitero, and Huang Yi. We also thank Ingo Bordon for excellent comments on an earlier version of this paper, as well as two anonymous referees for very helpful recommendations.
} 


\section{Introduction}

Long-term private financial flows-including foreign direct investment (FDI), cross-border bank lending, bond and equity financing, as well as remittances_-may assume a crucial role in helping attain the Sustainable Development Goals (SDGs). Even though bond financing accounted for only 14 per cent of international private capital flows to developing countries in 2012, much lower than FDI, which made up about 60 per cent, it was much more important than Official Development Assistance (ODA) and Other Official Flows (OOF), which together made up only 1 per cent total international capital flows to developing countries in the same year (World Bank, 2013, p. 23).

To date, local currency bond markets (LCBMs) still play a minor role in the long-term private financing of Sub-Saharan African (SSA) economies, because capital markets are not well developed in this region. However, experiences of developing countries in other regions, such as Asia, suggest that LCBMs can potentially take on an important role in SSA too in the future. One indicator for the nascent stage of bond market development in SSA is the outstanding stock of government securities, which accounted for only 14.8 per cent of GDP in 2010 on average, being significantly lower than in other developing, emerging, and advanced economies. A further indicator of the shallowness of the LCBMs in SSA is that government securities issues significantly exceed corporate bond issues. Government securities made up nearly 90 per cent of total outstanding local currency denominated bonds in 2010. Compared to other regions of the world, the difference between these two types of securities is much larger in SSA (IMF, 2013, p. 40; Mu et al., 2013).

The development of LCBMs can contribute to mobilizing long-term domestic financial resources for achieving the SDGs, in particular for much-needed local or regional infrastructure investments. One main prerequisite for LCBMs meeting this goal is that capital markets as well as banks are able to assume their transformation role of converting relatively short-term deposits into long-term investments in infrastructure (World Bank, 2013, p. 24). By means of issuing infrastructure project bonds, capital is generated for specific projects. ${ }^{1}$ Kenya, for example, has successfully issued infrastructure bonds since 2009, raising money for water, road, and energy projects. The issuance of these government bonds has made it easier to issue corporate bonds of private or state-owned enterprises (IMF, 2014, p. 48).

\footnotetext{
${ }^{1}$ See, for instance, Mbeng Mezui (2012).
} 
Even though the significance of LCBMs in SSA for long-term investments is currently limited compared to alternative sources of long-term financing, LCBMs represent a promising instrument to provide long-term financing in the future. There may be various benefits in developing LCBMs in SSA. One main advantage is that LCBMs can contribute to improving capital allocation by offering alternative sources of financing and by diversifying risks among different groups of investors, both domestic and foreign. Another advantage is that domestic debt markets may contribute to a better financial intermediation and promote domestic investments. Moreover, LCBMs may alleviate the effects of debt and financial crises as well as other external shocks on the domestic economy. By reducing the dependency on foreign debt, LCBMs can also alleviate the 'original sin' problem and thereby reduce the risk of currency mismatches (Eichengreen and Hausmann, 1999; Khan, 2005; IMF, 2007, p. 55, and 2013, p. 39; Adelegan and Radzewicz-Bak, 2009, p. 3; Berensmann, 2010; Maziad et al., 2013, pp. 5-7; Essers et al., 2015, pp. 6-7). Moreover, as pointed out by Arnone and Presbitero (2010), building the institutional infrastructure for the issuance of domestic public debt can support the organization and functioning of local financial markets at large.

Against this backdrop, this article examines the factors which may impede and promote LCBM development in SSA. Our analysis focuses on sovereign debt, not only because this makes up the lion's share of LCBMs in SSA, but also because liquid local currency sovereign debt markets are considered a prerequisite for the development of vibrant local currency corporate bond markets (e.g. Dittmar and Yuan, 2008). The next section briefly presents recent trends and challenges of LCBM development in SSA. Subsequently, section III econometrically analyses patterns of LCBM development in SSA. Section IV highlights some experiences with bond market development from emerging markets in Asia and Latin America and discusses possible lessons for countries in SSA. Section V concludes with policy recommendations.

\section{Recent trends in and challenges for LCBM development in SSA}

A key development over the past decade has been the increasing reliance of governments in SSA on markets for debt financing. As Figure 1 shows, governments in SSA have increasingly used marketable debt, comprising bonds, notes, and money market instruments, as opposed to nonmarketable debt, which consists mainly of loans by official bilateral or multilateral creditors, such as the World Bank, and loans by commercial banks. There was a slight decrease in reliance on markets for debt financing in 2008 and 2009, possibly in response to actual or expected 
difficulties in raising funds through markets in the wake of the global financial crisis. Yet, overall, there is a positive trend in the share of marketable debt to total debt.

Figure 1: Central government marketable debt (\% of total central government debt) in SSA

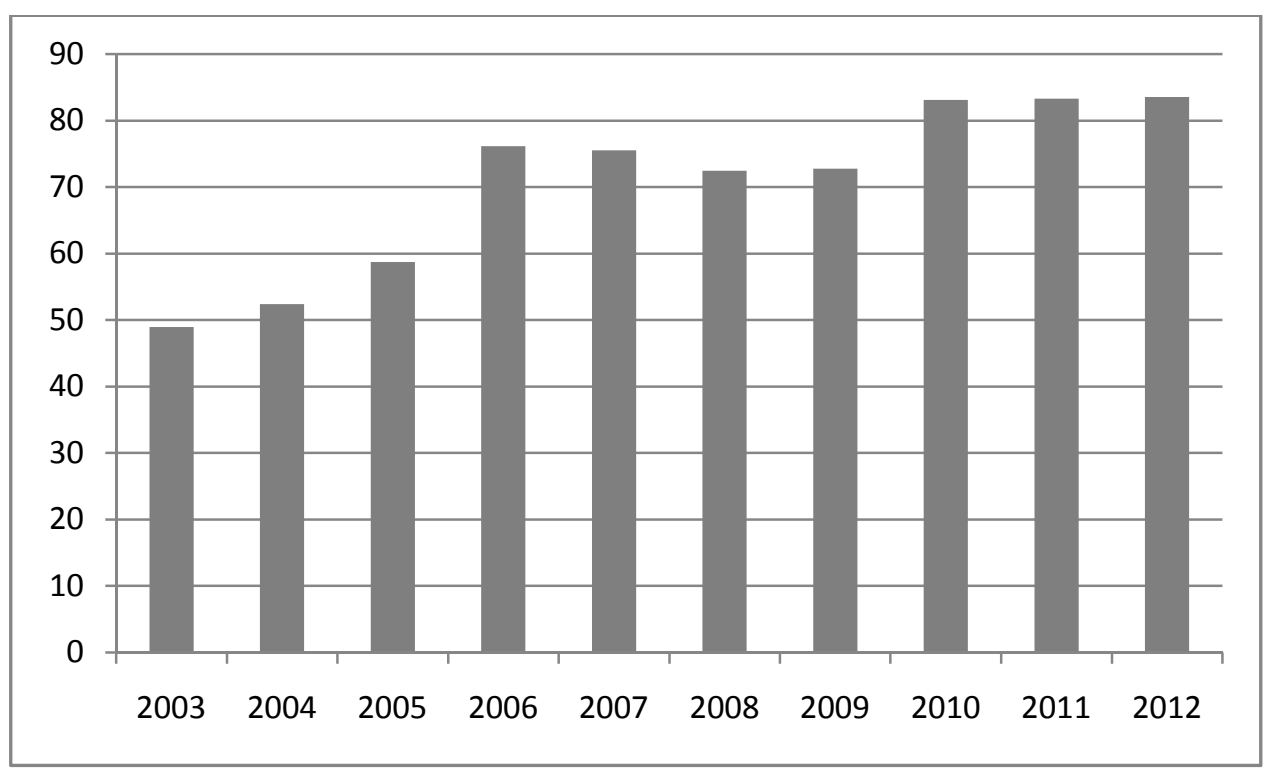

Note: Figure includes Angola, Cameroon, Gabon, Kenya, Madagascar, Malawi, Mauritius, Mozambique, Namibia, Nigeria, Sierra Leone, South Africa, Tanzania, Uganda and Zambia. No data are available for Angola from 2010 onwards, for Gabon from 2003 to 2006 and from 2010 onwards, and for Namibia from 2008 onwards.

Source: OECD (2013).

The regional aggregates disguise considerable variation in the role debt financing through markets plays for different SSA countries. For instance, while between 2008 and 2012 the average ratio of marketable debt to total debt amounts to 100 per cent in Tanzania, 96 per cent in South Africa, and 86 per cent in Nigeria and Mauritius, this share amounts to only 51 per cent in Kenya, 40 per cent in Uganda, 20 per cent in Sierra Leone and Madagascar, 17 per cent in Cameroon, and 8 per cent in Mozambique. Table 1 presents these cross-national differences for a selection of countries in SSA for which data are available, for the period before and after the global financial crisis. It is remarkable that the average ratios of marketable debt to total debt increased compared to the pre-crisis period, notably in the categories of low-income and lower middle-income countries, as classified by the World Bank. This suggests that the overall positive trend in the use of markets for debt financing in SSA shown in Figure 1 has not been driven by individual or upper middle-income countries. 
Table 1: Central government marketable debt (\% of total central government debt) in selected SSA countries

\begin{tabular}{|l|r|r|r|}
\hline Low-income countries & $\mathbf{2 0 0 3 - 7}$ & $\mathbf{2 0 0 8}-\mathbf{1 2}$ & $\mathbf{2 0 1 2}$ \\
$\quad$ Kenya & 44.0 & 51.3 & 52.9 \\
$\quad$ Madagascar & 15.8 & 20.7 & 18.1 \\
$\quad$ Malawi & 30.0 & 52.1 & 34.0 \\
$\quad$ Mozambique & 4.7 & 9.0 & 11.2 \\
$\quad$ Sierra Leone & 12.6 & 20.1 & 20.6 \\
$\quad$ Tanzania & 100.0 & 100.0 & 100.0 \\
$\quad$ Uganda & 23.4 & 39.8 & 40.4 \\
Average low-income countries & $\mathbf{3 2 . 9}$ & $\mathbf{4 1 . 9}$ & $\mathbf{3 9 . 6}$ \\
Lower middle-income countries & & & \\
$\quad$ Cameroon & 8.3 & 17.3 & 21.7 \\
$\quad$ Nigeria & 49.0 & 85.9 & 87.6 \\
$\quad$ Zambia & 30.0 & 53.9 & 46.0 \\
Average lower middle-income & & & \\
countries & $\mathbf{2 9 . 1}$ & $\mathbf{5 2 . 3}$ & $\mathbf{5 1 . 8}$ \\
Upper middle-income countries & 18.8 & & \\
$\quad$ Angola & & 49.1 & 81.0 \\
$\quad$ Mauritius & 100.0 & 86.3 & 96.3 \\
$\quad$ South Africa & 95.7 & 95.5 & $\mathbf{8 8 . 6}$ \\
Average upper middle-income & & & $\mathbf{7 7 . 0}$ \\
countries
\end{tabular}

Note: ${ }^{\text {a }}$ Data for Angola in the time period 2008-12 are only available for 2009.

Source: OECD (2013).

Another trend is that marketable debt is increasingly issued in local currency. Specifically, there has been a slight increase in the ratio of local currency marketable debt to total marketable debt between 2003 and 2012, with a dip in the crisis year 2009 (Figure 2). 
Figure 2: Local currency central government marketable debt (\% of central government marketable debt) in SSA

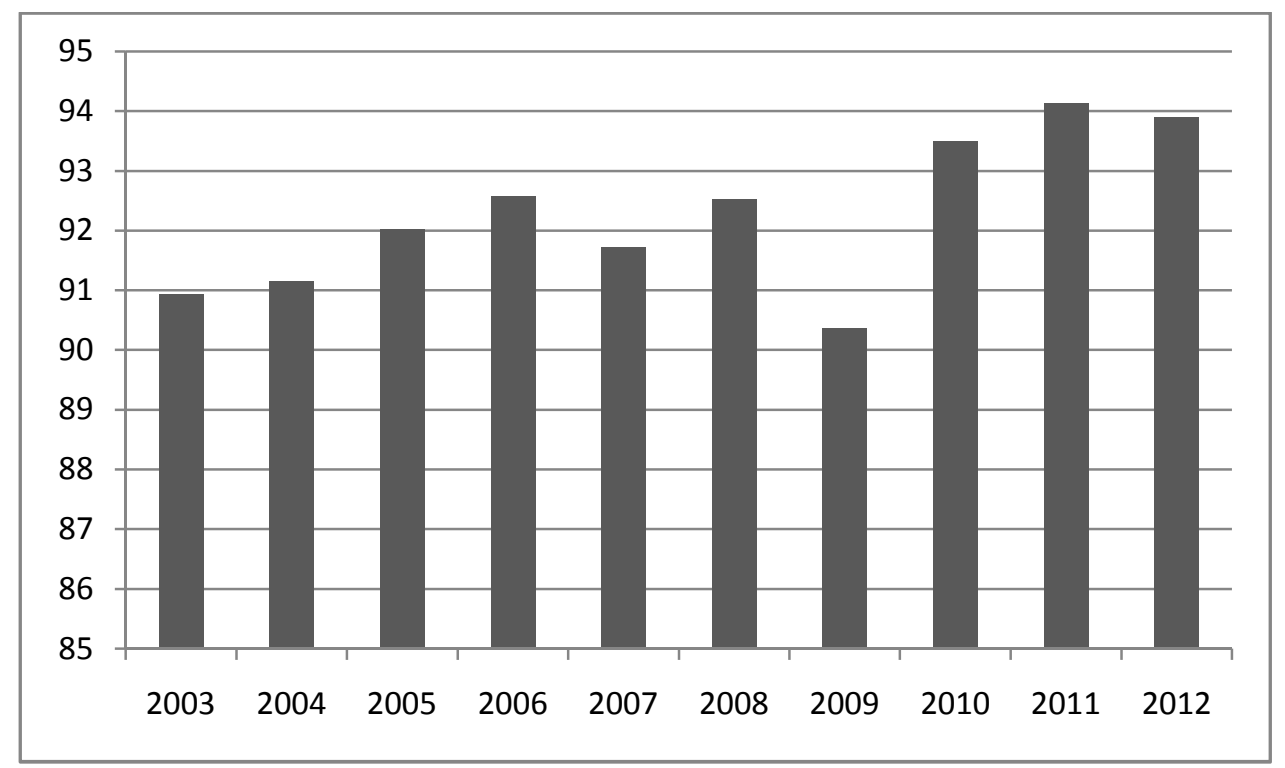

Note: Figure includes Angola, Cameroon, Gabon, Kenya, Madagascar, Malawi, Mauritius, Mozambique, Namibia, Nigeria, Sierra Leone, South Africa, Tanzania, Uganda, and Zambia. No data are available for Angola from 2010 onwards, for Gabon from 2003 to 2007 and from 2010 onwards, and for Namibia from 2008 onwards.

Source: Compiled with data from OECD (2013).

If we turn to local currency treasury bond market development, the picture that emerges is more ambiguous. At present, the database of the African Development Bank's African Financial Market Initiative (AFMI) seems to have the largest coverage of local currency treasury bonds, in terms of both countries and years. Since there remain significant gaps in the dataset for many SSA countries up to the year 2006, in the following analysis we focus on developments within the years 2007 to 2012. As Figure 3 shows, local currency treasury bond issuance as share of GDP in SSA increased from 2007 onwards and decreased after 2010. The regional aggregate disguises significant differences in the amounts of local currency sovereign bonds issued between SSA countries in different income groups. While local currency treasury bonds issued in the period 2010-12 on average amounted to 8.6 per cent and 7.1 per cent of GDP in Mauritius and Ghana, respectively, it was virtually zero in Benin (Table 2). However, there has been an increase in the average size of local currency treasury bonds in all three groups of countries, lowincome, lower middle-income, and upper middle income countries, from the first period (20079) to the second period (2010-12). In addition, the data suggest that low-income countries issue on average a smaller amount of bonds as share of GDP than do middle-income countries. As 
Table 2 shows, between 2010 and 2012, the average debt issued in low-income countries was almost 2 per cent of GDP, whereas in lower middle-income and upper middle-income countries the average debt issued amounted to more than 3 per cent of GDP. That said, the amounts issued by low-income African countries in recent years are not negligible. In 2012, for instance, the total amount of local currency bonds issued in our sample of low-income countries amounts to 2.5 per cent of GDP of these countries. ${ }^{2}$ This is equivalent to 28 per cent of net ODA received by these countries, or 34 per cent of their net inflows of FDI in 2012.

Figure 3: Local currency treasury bonds issued (\% of GDP) in SSA

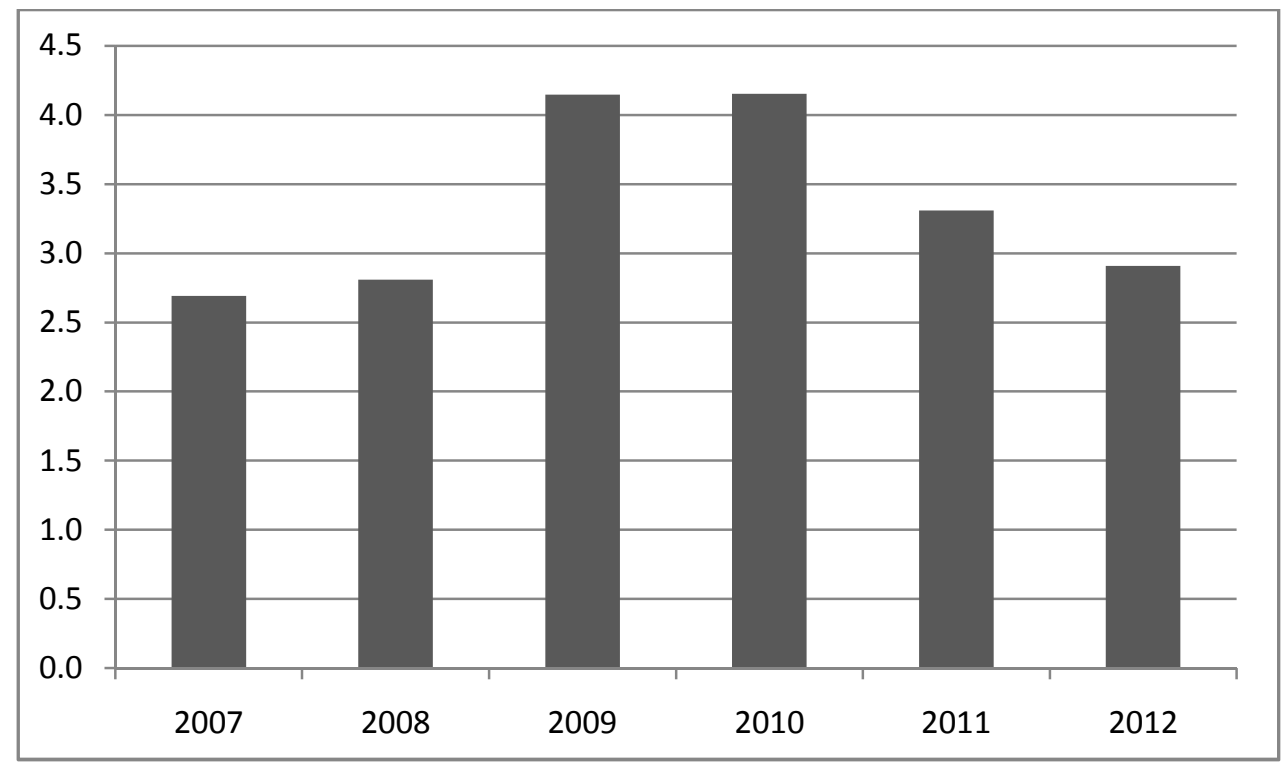

Note: Figure includes Angola, Benin, Botswana, Burkina Faso, Cabo Verde, Côte d'Ivoire, Gabon, Ghana, Kenya, Mali, Mauritius, Mozambique, Namibia, Nigeria, Senegal, South Africa, Tanzania, Togo, Uganda, and Zambia. Data for Benin for 2010 are missing. Data for Botswana are included from 2008 onwards. Data for Burkina Faso for 2008 are missing. Data for Mali and for Mozambique are included from 2008 onwards.

Source: Compiled with data from African Development Bank (AfDB, 2014).

\footnotetext{
${ }^{2}$ In 2012, Benin, Burkina Faso, Kenya, Mali, Mozambique, Tanzania, Togo, and Uganda are included in our sample of low-income countries.
} 
Table 2: Local currency treasury bonds issued (\% of GDP)

\begin{tabular}{|c|c|c|c|}
\hline & Average 2007-9 & $\begin{array}{c}\text { Average 2010- } \\
12 \\
\end{array}$ & 2012 \\
\hline \multicolumn{4}{|l|}{ Low-income countries } \\
\hline Benin & 1.3 & 0.0 & 0.0 \\
\hline Burkina Faso & 1.7 & 0.9 & 0.6 \\
\hline Kenya & 3.8 & 5.7 & 5.0 \\
\hline Mali & 0.7 & 0.3 & 0.0 \\
\hline Mozambique & 0.1 & 0.7 & 0.8 \\
\hline Tanzania & 1.2 & 1.9 & 1.9 \\
\hline Togo & 0.6 & 2.3 & 2.4 \\
\hline Uganda & 2.3 & 2.9 & 2.8 \\
\hline Average low-income countries & 1.4 & 1.8 & 1.7 \\
\hline \multicolumn{4}{|l|}{ Lower middle-income countries } \\
\hline Cabo Verde & 3.3 & 4.7 & 4. 7 \\
\hline Côte d'Ivoire & 0.9 & 2.5 & 2.0 \\
\hline Ghana & 4.0 & 7.1 & 7.7 \\
\hline Nigeria & 2.6 & 1.5 & 1.2 \\
\hline Senegal & 1.0 & 2.3 & 3.5 \\
\hline Zambia & 1.6 & 1.8 & 1.7 \\
\hline Average lower middle-income & 2 & 32 & 35 \\
\hline \multicolumn{4}{|l|}{ Upper middle-income countries } \\
\hline Angola & 1.2 & 0.9 & 0.8 \\
\hline Botswana & 1.5 & 1.2 & 0.5 \\
\hline Gabon & 0.5 & 0.0 & 0.0 \\
\hline Mauritius & 7.5 & 8.6 & 9.3 \\
\hline Namibia & 0.8 & 2.0 & 2.2 \\
\hline South Africa & 5.0 & 6.4 & 5.4 \\
\hline $\begin{array}{l}\text { Average upper middle-income } \\
\text { countries }\end{array}$ & 2.7 & 3.2 & 3.0 \\
\hline
\end{tabular}

Source: AfDB (2014).

To what extent have LCBMs in SSA deepened in recent years? Using the ratio of local currency treasury bonds outstanding to GDP as a measure of the depth of the local currency treasury bond market, Figure 4 shows that in SSA as a whole LCBMs have deepened between 2007 and 2012. That said, the amount of local currency treasury bonds outstanding has slightly declined between 2010 and 2012. Table 3 presents averages of local currency bonds outstanding by income group and a comparison of these averages in the time period 2007-9 and the time period 2010-12. The data presented in Table 3 show that LCBMs have, on average, deepened in the recent time period, a finding that holds for the group of low-income, lower middle-income and upper middle-income countries. In addition, the data indicate a positive relationship between the level 
of economic development and LCBM depth: in both time periods under consideration, the relative size of LCBMs is smallest in low-income countries and largest in upper middle-income countries. 
Table 3: Local currency treasury bonds outstanding (\% of GDP)

\begin{tabular}{|c|c|c|c|}
\hline & $\begin{array}{r}\text { Average 2007- } \\
9\end{array}$ & $\begin{array}{r}\text { Average 2010- } \\
12 \\
\end{array}$ & Average 2012 \\
\hline \multicolumn{4}{|l|}{ Low-income countries } \\
\hline Benin & 2.5 & 2.7 & 2.2 \\
\hline Burkina Faso & 2.2 & 3.8 & 4.0 \\
\hline Kenya & 10.5 & 21.8 & 22.7 \\
\hline Malawi & 0.8 & 0.2 & 0.1 \\
\hline Mali & 1.0 & 1.6 & 1.2 \\
\hline Mozambique & 2.2 & 2.4 & 2.6 \\
\hline Tanzania & 4.2 & 5.7 & 6.4 \\
\hline Togo & 3.2 & 5.3 & 7.5 \\
\hline Uganda & 6.8 & 7.4 & 7.5 \\
\hline Average low-income countries & 3.7 & 5.7 & 6.0 \\
\hline \multicolumn{4}{|l|}{ Lower middle-income countries } \\
\hline Cabo Verde & 17.0 & 22.0 & 23.2 \\
\hline Côte d'Ivoire & 2.9 & 6.3 & 8.2 \\
\hline Ghana & 9.4 & 13.4 & 15.3 \\
\hline Nigeria & 7.1 & 5.7 & 5.8 \\
\hline Senegal & 2.8 & 5.7 & 7.6 \\
\hline Zambia & 5.3 & 5.6 & 6.1 \\
\hline Average lower middle-income & 74 & 08 & 110 \\
\hline \multicolumn{4}{|l|}{ Upper middle-income countries } \\
\hline Angola & 1.5 & 4.3 & 4.3 \\
\hline Botswana & 3.7 & 5.1 & 5.2 \\
\hline Gabon & 1.2 & 0.3 & 0.2 \\
\hline Mauritius & 27.2 & 34.9 & 35.8 \\
\hline Namibia & 10.1 & 9.3 & 9.3 \\
\hline South Africa & 25.8 & 32.1 & 33.1 \\
\hline $\begin{array}{l}\text { Average upper middle-income } \\
\text { countries }\end{array}$ & 11.6 & 14.3 & 14.6 \\
\hline
\end{tabular}

Source: AfDB (2014). 
Figure 4: Local currency treasury bonds outstanding (\% of GDP) in SSA

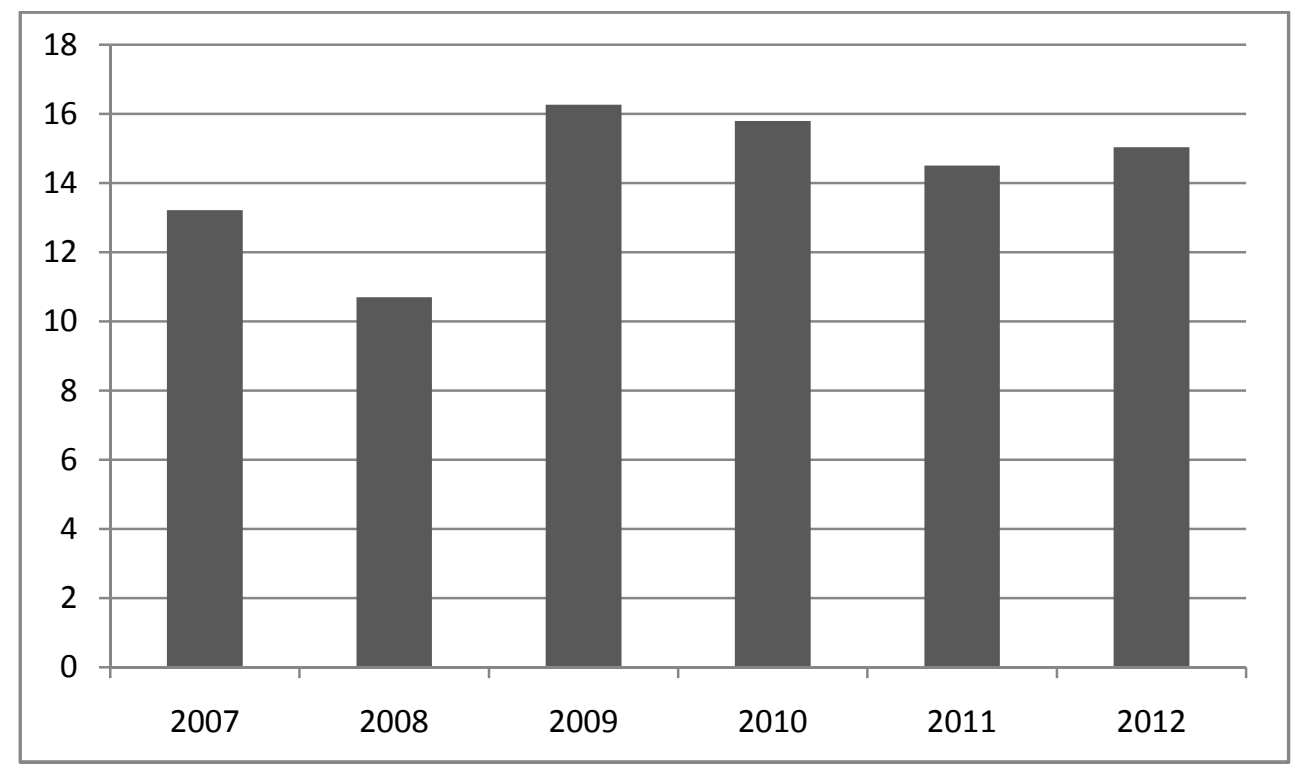

Note: Figure includes Angola, Benin, Botswana, Burkina Faso, Cabo Verde, Côte d'Ivoire, Gabon, Ghana, Kenya, Malawi, Mali, Mauritius, Mozambique, Namibia, Nigeria, Senegal, South Africa, Tanzania, Togo, Uganda, and Zambia. Data for Mali are included from 2008 onwards. Source: Compiled with data from AfDB (2014).

The maturity profile presents another important indicator for LCBM development (Bua et al., 2014). Short maturities enhance rollover risks and contribute to macroeconomic vulnerability. Yet governments may prefer to issue short-term debt if the yield curve is strongly upwardsloping, since borrowing costs increase significantly with longer tenors. Generally speaking, LCBMs in SSA are still shallow, especially for longer-dated maturities, but several governments-including South Africa, Botswana, and Nigeria-have been able to issue longerterm debt. The average maturity of bonds differs significantly among SSA countries, as depicted in Figure 5. It is notable that in Ghana, where the local currency treasury bond market has deepened significantly over recent years, the average tenure of these bonds is still one of the shortest across the region. This shows that confidence in Ghanaian local currency government bonds is still limited.

Short maturities of government securities represent a major structural challenge for LCBM development in SSA. If governments issue only short-term papers, this obstructs the development of secondary markets, since investors are likely to hold their papers to maturity. Moreover, along with an insufficient issuance of government securities, it will prevent the emergence of a yield curve for government securities which can be used to price cash-flows off 
the curve. A liquid yield curve is generally seen as important for price discovery in the bond market. The lack of a secondary market and a yield curve for sovereign bonds inhibits the development of corporate bond markets, since government bonds cannot assume their benchmarking role (Dittmar and Yuan, 2008). And of course, undeveloped domestic debt markets increase rollover risks, generate higher interest rates, and reduce the effectiveness of monetary policy (IMF, 2013, p. 40).

Figure 5: Average tenure of local currency treasury bonds issued (years), 2013

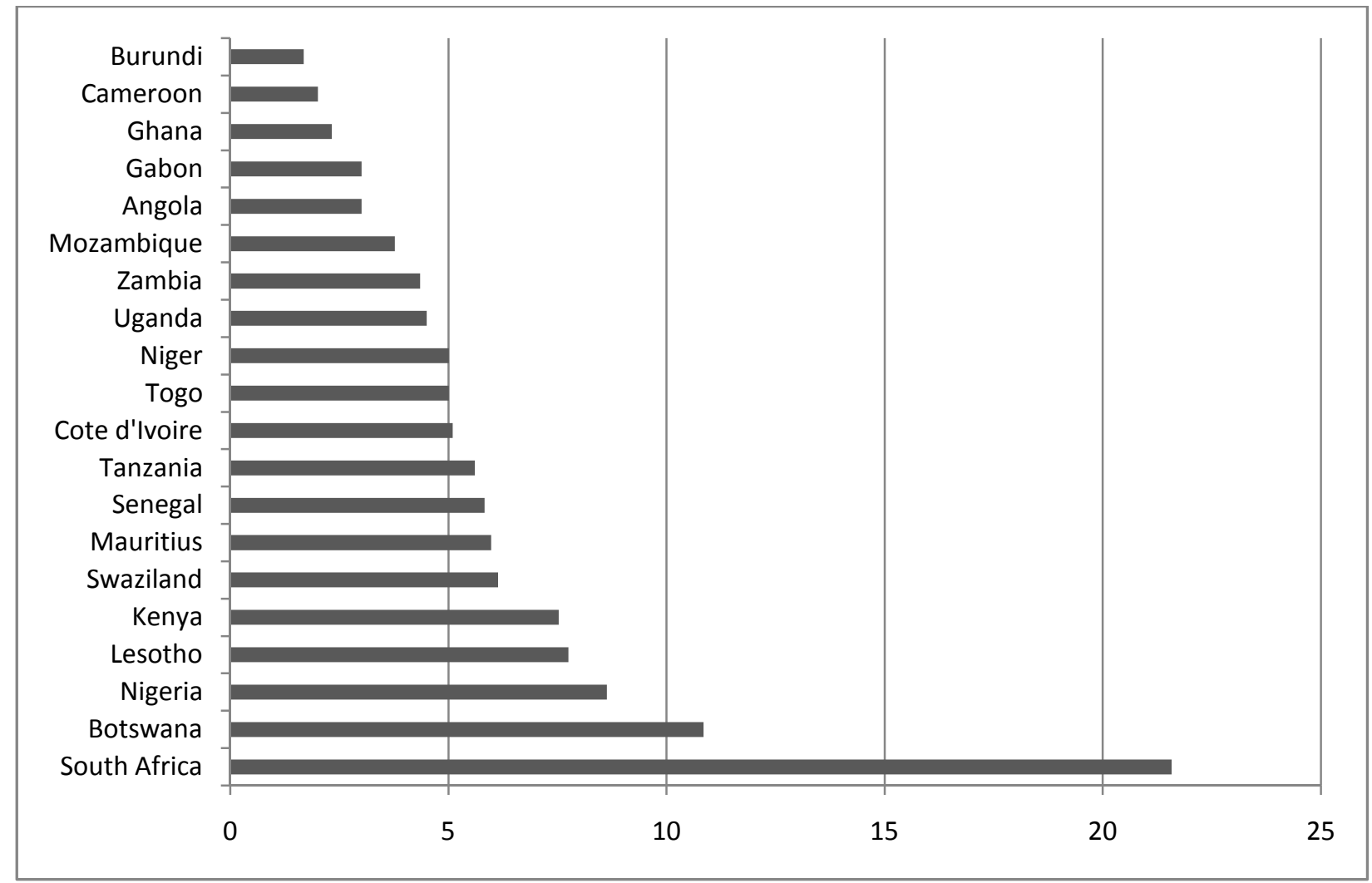

Source: Compiled with data from African Financial Markets Database.

The cost of bond borrowing measured by the average yield also differs substantially across SSA economies, as shown in Figure 6. The yield is an important indicator for LCBM development because it reflects risk perceptions and confidence in the market. Bua et al. (2014, p. 11) find that in low-income countries the cost of domestic public debt and the share of long-term instruments is negatively correlated, suggesting that 'debt portfolios of longer maturity face lower cost than debt portfolios of shorter maturity'. This can be observed in SSA, too. While the South African government, for instance, benefits from comparatively lower yields and longer 
maturities, a country like Ghana, conversely, faces high and volatile yields even for relatively short maturities.

Figure 6: Average issue yield of local currency treasury bonds (in \%), 2013

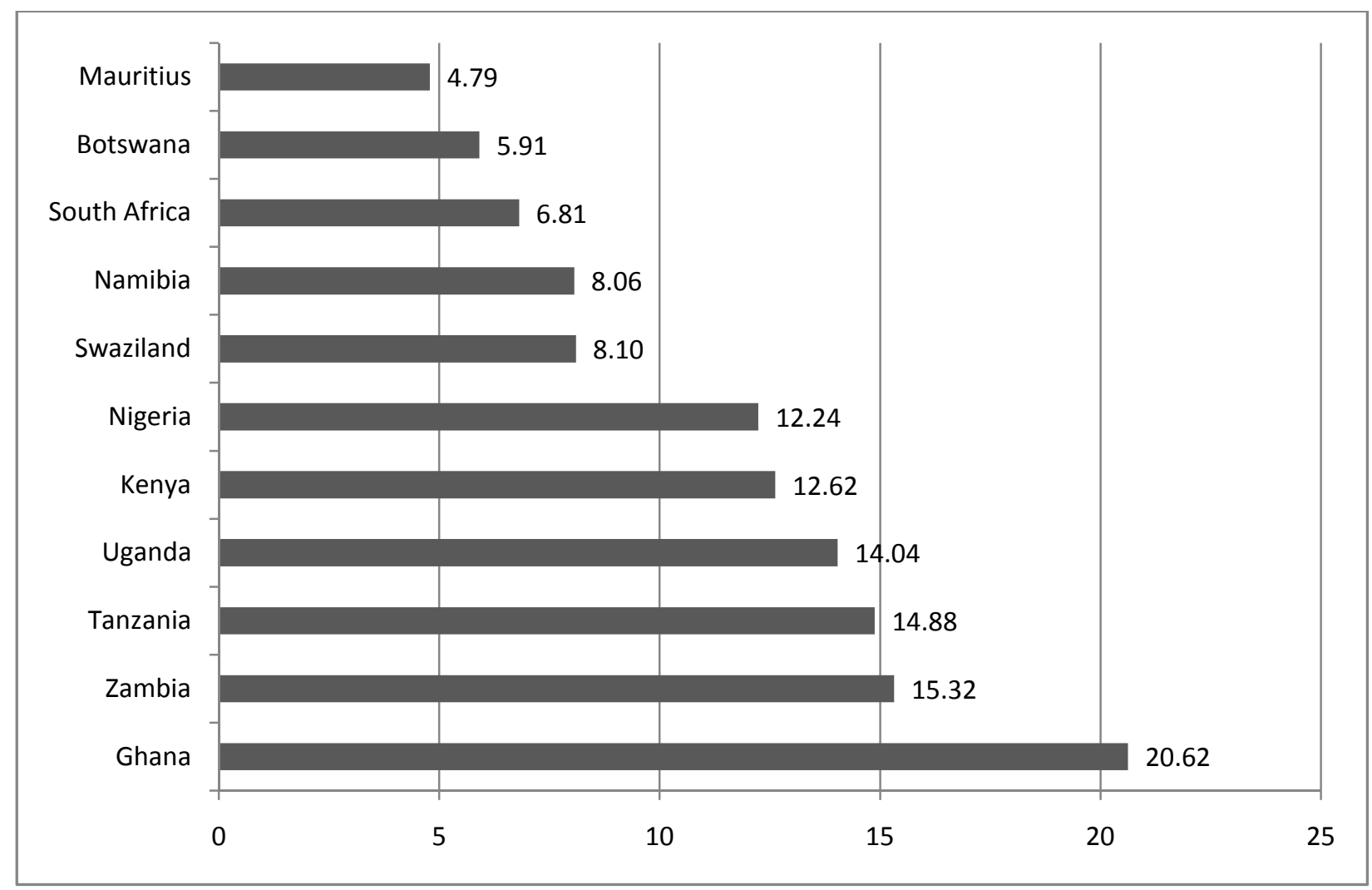

Source: Compiled with data from African Financial Markets Database.

Lastly, the ownership of local-currency marketable debt represents an additional guide for the developmental stage of LCBMs. Since only few countries in SSA have a centralized information system with comprehensive historical trade data, databases of bond holders from national sources are often patchy, and flow of funds data are usually not available for most SSA economies. Table 4 provides information on ownership of local-currency marketable debt, with a distinction between resident and non-resident bond holders. Although the data shown in the table are incomplete, the situation is that—with the notable exception of South Africa-local-currency marketable debt in SSA is predominantly or even exclusively held by domestic investors. Meanwhile, South Africa, the most developed market in the region, has seen a decline in the share of local-currency marketable debt held by residents from 95 per cent in 2004 to 62 per cent in 2013, mirroring the increasing confidence of foreign investors in the South African LCBM. 
By contrast, in Kenya the share of local-currency marketable debt held by residents remained high, with 97 per cent in 2003 and 99 per cent in 2013.

The domestic investor base is generally narrow and highly concentrated (Arnone and Presbitero, 2010). In most SSA countries, local-currency marketable debt is predominantly held by domestic commercial banks. Exceptions are Malawi, Mauritius, Nigeria, South Africa, Tanzania, Uganda, and Zambia, where domestic institutional funds (and in some cases also the central bank) hold significant portions of local-currency marketable debt. South Africa is again a special case, given that only 23 per cent of resident ownership of local-currency marketable debt was with domestic commercial banks in 2013, while 77 per cent of all resident holdings was with domestic institutional funds.

A restricted and undifferentiated investor base in domestic debt markets which is largely concentrated on commercial banks is a serious structural challenge. A narrow investor base exists although auctions of government debt have been oversubscribed in many countries, including those of the West African Economic and Monetary Union (IMF, 2015, p. 7). As pointed out by Sy (2007), there are various reasons why local commercial banks in SSA typically have a big appetite for government securities. With high yields even at relatively short maturities, banks have a strong incentive to invest in (supposedly) safe government securities rather than private-sector projects. Moreover, in most SSA countries interest earned on government bonds is tax exempt, while sovereign bonds carry a zero risk weight in the calculation of capital adequacy ratios. While this improves the funding situation of the government, the drawback, however, is a possible crowding out effect, i.e. when commercial banks allocate a large share of their assets to sovereign debt, private saving may be used for government financing rather than private investment (Bua et al., 2014). Abbas and Christensen (2010) have shown that the growth effect of domestic public debt is higher for marketable instruments that are held by non-bank investors. A more diversified ownership is crucial to eliminating the crowding-out effect. Moreover, a more differentiated investor base can reduce financial vulnerability since a large exposure of domestic banks to their home governments' debt can cause 'disruptive self-reinforcing feedback loops' (Gros, 2013, p. 93) when either the banks or the sovereign encounter problems. Last but not least, a narrow investor base also hinders the development of secondary markets. 
Table 4: Ownership of local-currency marketable debt (amounts outstanding at the end of period, million euro)

\begin{tabular}{|c|c|c|c|c|c|c|c|c|c|c|c|}
\hline & 2003 & 2004 & 2005 & 2006 & 2007 & 2008 & 2009 & 2010 & 2011 & 2012 & 2013 \\
\hline Angola & 627 & 1,121 & 1,518 & 1,864 & 2,735 & 9,855 & 6,506 & 5,431 & 5,822 & 6,645 & \\
\hline Resident & 627 & 1,221 & 1,518 & 1,841 & 2,735 & 9,855 & 6,506 & 5,431 & 5,822 & 6,645 & \\
\hline Non-resident & & & & 23 & 0.06 & & & & & & \\
\hline Cameroon & 814 & 401 & 383 & 295 & 262 & 249 & 248 & 520 & 692 & 698 & 1,153 \\
\hline Resident & 814 & 401 & 383 & 295 & 262 & 249 & 248 & 456 & 628 & 654 & 1,121 \\
\hline Non-resident & & & & & & & & 64 & 64 & 44 & 32 \\
\hline Gabon & & & & & & 104 & 83 & & & & \\
\hline Resident & & & & & & 42 & 34 & & & & \\
\hline Non-resident & & & & & & 61 & 49 & & & & \\
\hline Kenya & 3,010 & 2,889 & 3,660 & 3,875 & 4,295 & 3,929 & 4,753 & 6,134 & 5,869 & 8,105 & $\mathbf{9 , 3 4 7}$ \\
\hline Resident & 2,915 & 2,851 & 3,584 & 3,820 & 4,284 & 3,903 & 4,729 & 6,105 & 5,809 & 8,001 & 9,262 \\
\hline Non-resident & 96 & 38 & 75 & 55 & 12 & 26 & 24 & 29 & 60 & 104 & 85 \\
\hline Madagascar & 714 & 396 & 411 & 437 & 461 & 371 & 378 & 417 & 453 & 510 & 476 \\
\hline Resident & 714 & 396 & 411 & 437 & 461 & 371 & 378 & 417 & 453 & 510 & 476 \\
\hline \multicolumn{12}{|l|}{ Non-resident } \\
\hline Malawi & 376 & 418 & 492 & 363 & 446 & 737 & 833 & 765 & 955 & 466 & 663 \\
\hline Resident & 376 & 418 & 492 & 363 & 446 & 737 & 833 & 765 & 955 & 466 & 663 \\
\hline \multicolumn{12}{|l|}{ Non-resident } \\
\hline Mauritius & 2,741 & 2,492 & 2,699 & 2,160 & 2,559 & 2,355 & 2,745 & 3,052 & 3,426 & 3,391 & 3,518 \\
\hline Resident & & & & & & 2,348 & 2,739 & 3,049 & 3,419 & 3,385 & 3,509 \\
\hline Non-resident & & & & & & 7 & 6 & 3 & 7 & 6 & 10 \\
\hline Mozambique & 160 & 102 & 193 & 156 & 139 & 120 & 103 & 428 & 637 & 685 & 794 \\
\hline Resident & & & & & & & & & & 685 & 794 \\
\hline \multicolumn{12}{|l|}{ Non-resident } \\
\hline \multicolumn{12}{|l|}{ Namibia } \\
\hline \multicolumn{12}{|l|}{ Resident } \\
\hline \multicolumn{12}{|l|}{ Non-resident } \\
\hline Nigeria & 7,696 & 7,652 & 9,995 & 10,472 & 12,622 & 12,644 & 15,177 & 22,789 & 27,737 & 31,824 & 33,204 \\
\hline Resident & 7,696 & 7,652 & 9,995 & 10,472 & 12,622 & 12,644 & 15,177 & 22789 & 27,737 & 31,824 & 33,204 \\
\hline \multicolumn{12}{|l|}{ Non-resident } \\
\hline Sierra Leone & 100 & 112 & 146 & 147 & 145 & 173 & 170 & 156 & 165 & 219 & 370 \\
\hline Resident & 100 & 112 & 146 & 147 & 145 & 173 & 170 & 156 & 165 & 219 & 370 \\
\hline \multicolumn{12}{|l|}{ Non-resident } \\
\hline South Africa & & 45,229 & 47,528 & 53,795 & 41,837 & 33,499 & 34,127 & 51,554 & $\mathbf{7 0 , 4 3 0}$ & $\mathbf{7 9 , 9 7 8}$ & 81,978 \\
\hline Resident & & 42,887 & 44,922 & 50,164 & 38,538 & 30,153 & 29,856 & 43,808 & 54,348 & 56,569 & 50,816 \\
\hline Non-resident & & 2,342 & 2606 & 3631 & 3300 & 3346 & 4271 & 7746 & 16,083 & 23,382 & 31,163 \\
\hline Tanzania & 954 & 1,029 & 1,748 & 1,488 & 1,855 & 1,387 & 1,164 & 1,714 & 1,674 & 2,222 & \\
\hline Resident & 954 & 1,029 & 1,748 & 1,488 & 1,855 & 1,387 & 1,164 & 1,714 & 1,674 & 2,222 & \\
\hline \multicolumn{12}{|l|}{ Non-resident } \\
\hline Uganda & 498 & 580 & 801 & 830 & 1,117 & 990 & 971 & 1,568 & 1,359 & 1,801 & 2,162 \\
\hline Resident & 498 & 580 & 801 & 830 & 1,117 & 990 & 971 & 1,568 & 1,359 & 1,801 & 1,959 \\
\hline Non-resident & & & & & & & & & & & 203 \\
\hline Zambia & 775 & 680 & 1,286 & 1,154 & 1,360 & 1,169 & 1,429 & 1,558 & 1,992 & 2,108 & 2,547 \\
\hline Resident & 775 & 680 & 1,286 & 1,154 & 1,360 & 1,169 & 1,429 & 1,558 & 1,992 & 2,108 & 2,547 \\
\hline Non-resident & & & & & & & & & & & \\
\hline
\end{tabular}

Note: Blank spaces mean that data are not available.

Source: Compiled with data from OECD (2015). 
The literature on bond market development has identified several other structural challenges in building up LCBMs which also appear to have a significant impact on the development of LCBMs in SSA. Several factors impede the issuance and monitoring of domestic debt, including a lack of an efficient institutional structure and a solid legal framework. Similarly, a lack of personnel trained in debt management, crucial for the issuance of domestic securities, contributes to the slow development of LCBMs in this region. A further problem is that government bonds could crowd out corporate bonds (IMF, 2007, pp. 64-5, and 2014, p. 40; Arnone and Presbitero, 2010). The slow pace of LCBM development in SSA is also related to the fact that often real interest costs of domestic issuance at longer maturities significantly exceed foreign borrowing costs, mainly because there is little trust in the markets due to high expected inflation rates and a lack of secondary market liquidity (IMF et al., 2013). Furthermore, there may be additional risks for investments in sustainable development owing to a lack of information and of internalization of environmental and social costs (Waygood, 2014).

The picture that emerges from this discussion of recent trends in the development of sovereign bond markets in SSA is that LCBMs are, indeed, at a nascent stage but have seen significant development progress over the past decade. This suggests that it is the right time to learn and think about ways to spur the continued development of these markets but also about potential risks of LCBM development. In following section, we focus on the first issue and examine empirically the factors which may hinder and promote the development of LCMBs.

\section{Patterns of LCBM development in Sub-Saharan Africa: cross-country econometric evidence}

What needs to be done to render LCBMs a reliable and major source of long-term financing for sustainable development in SSA? This section approaches the question empirically by examining the factors that influence LCBM development. Our aim is to explore what variables have been associated with LCBM development in SSA and whether the correlates of LCBM development in SSA are different from elsewhere. Specifically, we employ cross-country econometric analysis to examine the broad patterns of LCBM development in SSA and learn about potential key drivers and obstacles. Our focus is on the relationship between a broad set of macroeconomic and institutional variables on the one hand and LCBM development on the other. 
There is little empirical research on the drivers of bond market development in SSA to date, and empirical scholarship on local currency bond market development in SSA is even more scant. ${ }^{3}$ One major reason for this is probably the historical predominance of external borrowing, and hence of foreign rather than local currency debt in low-income countries (Bua et al., 2014). Another reason is most certainly the poor quality and availability of data on debt in SSA. The data situation has only improved very recently, opening up opportunities for empirical research on the patterns of bond market development in SSA. Bua et al. (2014), for instance, introduce a new dataset on domestic debt in low-income countries which covers 40 countries, of which 29 are in SSA, in the period 1971-2011 and provides cross-country comparable data both on the stock of domestic debt and its structure, including detailed information on maturity, currency composition, creditor base, and the type of instruments. In the dataset constructed by Bua et al. (2014), however, domestic debt refers primarily to debt owed to residents, rather than to debt denominated in local currency, which is the focus of our paper. In another recent study, Essers et al. (2015) use data on local currency debt in SSA from the OECD's African Central Government Debt Statistical Yearbook (OECD, 2013) to examine the drivers of LCBM development. Yet their sample remains limited to 15 African countries and the time period 2003-12 because data for their dependent variable, year-end outstanding marketable central government debt in or indexed to local currency as a percentage of GDP, are only available for relatively few African countries and years.

Drawing from the African Development Bank's AFMI database, among others, we compile a dataset comprising 27 SSA countries, ranging over a maximum of 14 years, namely the period 2000-13. For sure, our sample size remains limited as well, weakening the power of statistical tests, and the time span of data on the stock of local currency bonds differs across countries in our dataset. Overall, however, we are confident that our analysis, which is based on a comparatively large dataset, will help to generate novel and more robust insights in LCBM development in SSA and the question of whether patterns in LCBM development in SSA are different from patterns elsewhere.

\footnotetext{
${ }^{3}$ For previous studies on the determinants of bond market development in SSA see Mu et al. (2013) and Adelegan and Radzewicz-Bak (2009). For a recent paper on the drivers of local currency bond market development see Essers et al. (2015).
} 


\section{(i) Model specification}

Following existing studies on the determinants of LCBM development such as Essers et al. (2015) and $\mathrm{Mu}$ et al. (2013), we employ a model of the following form:

$$
Y_{i, t}=\alpha+\beta X_{i, t-1}+\delta \mu_{i}+\varepsilon_{i, t}
$$

where $Y_{i, t}$ is the dependent variable, i.e. the outstanding amount of local currency treasury bonds as a percentage of GDP for country $i$ in year $t$; this variable is our indicator for the depth of LCBMs; $X_{i, t-1}$ is a vector of 1-year lagged explanatory variables derived from the literature and described below; $\mu_{i}$ are country-specific effects and $\varepsilon_{i, t}$ is an error term. While it is not possible to establish causal relationships with the data and models we use, we seek at a minimum to ensure that changes in the explanatory variable precede changes in the dependent variable by using lags of the explanatory variables.

Our main interest is to explore the variation of LCBM development across countries in SSA, rather than the variation within countries over time with models using country fixed effects (FE). The reasons for the focus on cross-country variation are threefold. First, comparing the overall, between, and within variation in Appendix Table A2 suggests that for our dependent and most explanatory variables, most variation arises from differences between countries rather than from changes within countries over time. This predominance of cross-country variation would render it difficult to discover significant relationships with fixed-effects models, which examine variation within countries over time. Second, our time series for LCBM development is relatively short, covering at a maximum 14 years and with the availability of data on LCBM development being limited for several countries before 2004. ${ }^{4}$ Finally, we focus on examining cross-country rather than within-country variation to allow for the comparison with other studies on the determinants of local currency bond market development such as Claessens et al. (2007), Eichengreen and Luengnaruemitchai (2004), and Eichengreen et al. (2008), each of which focuses on the cross-country dimension of variation in LCBM development.

Specifically, we employ two different estimators. First, as our baseline model, we employ pooled ordinary least squares (POLS) with panel-corrected standard errors (PCSE) to address panel heteroscedasticity; this model assumes a common intercept across countries $(\delta=0)$. Second, as our main model, we employ the random effects (RE) model with heteroscedasticity-robust standard errors and a correction for autocorrelation, following other studies such as Eichengreen

\footnotetext{
${ }^{4}$ Specifically, data on local currency bond market development for the period from 2000 to 2003 is only available for half of the countries in our sample.
} 
and Luengnaruemitchai (2004) and Eichengreen et al. (2008); this estimator models the countryspecific constant terms $\mu_{i}$ as distributed randomly across countries and as independent from the other explanatory variables. ${ }^{5}$

\section{(ii) LCBM development—-the dependent variable}

We complement the existing literature by using data on local currency marketable central government bonds from the African Development Bank's AFMI. The AFMI data are available for a larger set of SSA countries than the set of countries included in the analysis by Essers et al. (2015), ${ }^{6}$ allowing us to gain insights on the correlates of LCBM development based on a different and larger set of countries. Our analysis is also different from other studies in that we focus on treasury bonds of a maturity of 1 year or greater. While for instance Essers et al. (2015) include short-term government securities with a maturity of less than 1 year in their analysis, we exclude them because short-term securities may be less appropriate instruments to finance the long-term investments needed to achieve the SDGs.

To measure the depth of LCBMs we use a variable capturing the total amount of medium- and long-term (maturity of 1 year or more) sovereign bonds in local currency outstanding as percentage of GDP (Bonds to GDP). The data on the total amount of bonds outstanding are from the AFMI database, the GDP data are from the World Development Indicators (WDI) of the World Bank (2014).

\footnotetext{
${ }^{5}$ With a view to facilitating the comparison with other studies and as additional robustness checks we used three additional estimators, the results of which are presented in the online appendix and are not discussed here in detail. First, we used a feasible generalized least squares (FGLS) which accounts for heteroscedastic error structures and panel-specific autocorrelation. Second, we used an FE model, which employs heteroscedasticity-robust standard errors and country and period FEs; an AR1 error model, which employs panel-corrected standard errors, country FE, and a Prais-Winston transformation to address the serial correlation of errors that was suggested by the Wooldridge test for serial correlation. Prais-Winston regressions involve a transformation of the data based on an estimate of the autocorrelation of the error terms. Country FE serve to capture country-specific constant factors, which, if not included in the model, would give rise to omitted variable bias. Yet eliminating time-invariant unobserved heterogeneity between countries comes at the cost of less efficient estimates. Specifically, it is not possible to examine the effects of time-invariant explanatory variables such as the legal origin and the cross-country dimension of variation in the explanatory variable more generally.

${ }^{6}$ Table A1 in the on-line appendix provides an overview over the African countries included in our sample and the sample of countries in some selected studies.
} 


\section{(iii) Explanatory variables}

In selecting the explanatory variables of the analysis, we follow various studies that examine the drivers of bond market development in Africa and elsewhere, allowing us to draw conclusions on whether the determinants of LCBM development in SSA are the same as elsewhere. The first group of explanatory variables relates to economic structure. There is some evidence for a positive relationship between country size and bond market development from studies which focus on regions other than Africa. ${ }^{7}$ One possible reason is that smaller-sized economies face greater obstacles to bond market development because economies of scale, which are important to reduce the costs of the establishment of LCBMs, are more difficult to realize (Claessens et al., 2007, p. 379). Another possible reason for a positive relationship between country size and bond market development is that larger economies offer greater diversification benefits to foreign investors (Hausmann and Panizza, 2003). The greater availability of (potential) buyers and sellers in larger-sized economies may also enhance bond market development by reducing price volatility (Eichengreen and Luengnaruemitchai, 2004). We use the natural log of GDP in constant 2005 United States dollars (USD) (ln GDP) to capture the size of an economy. Data are from the WDI database.

The discussion of recent trends in LCBM development in the previous section suggests that there is a positive relationship between LCBM development and the stage of economic development, a finding that is in line with some studies on the determinants of financial market development more generally. ${ }^{8}$ We use the natural log of the GDP per capita in constant 2005 USD (In GDP per capita) as an indicator of the level of economic development. The data are from the WDI.

Following Essers et al. (2015) and $\mathrm{Mu}$ et al. (2013), we also include a measure for trade openness. Trade openness may be positively correlated with financial development for several reasons. One reason may be that trade openness supports bond market development indirectly by encouraging an economic dynamic and institutional development in ways not completely captured by other variables (Eichengreen et al., 2008, p. 265). Another reason may be that established industrial interests may be less opposed to financial development despite encouraging market entry and benefiting newcomers when an economy allows cross-border trade flows (Rajan and Zingales, 2003). ${ }^{9}$ Yet a negative correlation is also plausible as countries which

\footnotetext{
${ }^{7}$ See for instance Eichengreen and Luengnaruemitchai (2004) and Claessens et al. (2007)

${ }^{8}$ See for instance Calderón and Liu (2003), who find a bi-directional relationship between finance and growth.

9 Specifically, Rajan and Zingales (2003) argue that incumbents' opposition to financial development, which encourages competition, will be weaker when an economy allows both cross-border trade and capital flows.
} 
are less integrated into world markets may have more incentive to develop domestic bond market markets in order to meet their financing needs (Adelegan and Radzewicz-Bak, 2009). We use WDI data on the total exports of goods and services as a share of GDP (trade to GDP) as an indicator for trade openness.

The size of the banking sector may also affect LCBM development. As banks play an important role in the development of liquid and functioning bond markets as dealers and market-makers, a more developed banking sector may be positively associated with bond market development (Eichengreen and Luengnaruemitchai, 2004, p. 13). In addition, in most SSA countries banks are the major class of government bond investors, suggesting a well-developed banking sector may enhance bond market development. However, a larger banking sector may also be associated with lower bond market development as powerful banks may oppose bond market development which breeds competition (Adelegan and Radzewicz-Bak, 2009) or as banks may substitute for bond financing. To probe the relationship between banking sector development and bond market development we employ as an indicator for the size of the banking sector private credit by banks as share of GDP (private credit to GDP), again taken from the World Bank's WDI database.

In addition, we include in some specifications a variable capturing the sum of rents from oil, minerals, and gas as a share of GDP (resource rents to GDP) from the WDI. ${ }^{10} \mathrm{We}$ include this structural economic variable because there is some evidence that resource dependence influences financial sector development (Beck, 2011), and resource dependence is quite prevalent in the African context. As regards LCBM development, the direction of the expected relationship is ambiguous. On the one hand, windfall gains from the extraction of natural resources may reduce the government's demand for financing and hence the incentives for LCBM development. On the other hand, large natural resource revenues increase the creditworthiness of the government which may encourage LCBM development. We include resource rents to GDP only in some of our baseline models because the availability of data for this variable is limited.

The second group of explanatory variables captures macroeconomic policy choices. One of these variables is the fiscal balance, defined as revenues minus expenditure. There is some evidence for a negative relationship between the fiscal balance and bond market development ( $\mathrm{Mu}$ et al., 2013; Essers et al., 2015). Yet a priori, the effect of the fiscal balance on bond market development is ambiguous: the government's financing needs may provide an important impetus

\footnotetext{
${ }^{10}$ Rents are defined in this study as the difference between the price of a commodity and the average cost of producing it.
} 
for LCBM development (Maziad et al., 2013). More negative fiscal balances (that is, larger fiscal deficits) may thus be positively associated with LCBM development. Yet large fiscal deficits may also raise doubts about macroeconomic stability and the government's ability to repay debt among potential investors and may thus have a negative influence on sovereign bond market development. Moreover, it is plausible to assume in the African context that the fiscal balance is endogenous to bond market development, as the ability to run fiscal deficits is likely to be constrained by bond market development (Essers et al., 2015). We follow other scholars such as Eichengreen and Luengnaruemitchai (2004), Adelegan and Radzewicz-Bak (2009), and Essers et al. (2015) in using the 3-year moving average of past budget balances as a share of GDP (fiscal balance to GDP) to reduce the effects of cyclical fluctuations. Data are, again, from the WDI database.

There is considerable empirical evidence that high inflation rates, indicating low monetary policy credibility and thus the likelihood that creditors' interest rate earnings might be eroded by inflation, are an obstacle to LCBM development (Hausmann and Panizza, 2003; Claessens et al., 2007; Essers et al., 2015). Moreover, in countries with a history of high inflation, governments are likely to face pressure to offer higher coupon rates on fixed-rate bonds ex ante, which could result in higher real interest costs if the expected inflation does not materialize ex post, rendering the issuance of such bonds less attractive to governments in the first place (Essers et al., 2015). We include WDI data on the inflation rate as measured by the annual change in the consumer price index as an explanatory variable and-admittedly imperfect—proxy of monetary policy credibility.

We also include capital account openness as an explanatory variable. Ex ante, the effect is ambiguous. On the one hand, an open capital account may help promote bond market development, for instance by encouraging foreign investors to enter the market. Claessens et al. (2007, p. 389) argue that an open capital account also raises the interest of domestic investors in bonds by exposing countries to greater market discipline. On the other hand, capital controls may prevent domestic capital from leaving the country and thus create a captive investor base (Forslund et al., 2011). We follow existing research, such as Essers et al. (2015), in using the Chinn-Ito Financial Openness Index (Ito and Chinn, 2014), a de jure measure of capital account openness. ${ }^{11}$ Higher values of the index indicate a more open capital account.

\footnotetext{
${ }^{11}$ For information on how the index is constructed see Ito and Chinn (2008).
} 
In addition we include the variable exchange rate volatility. Eichengreen and Luengnaruemitchai (2004), for instance, find that lower exchange rate volatility is positively correlated with bond market development. The reason may be that exchange rate stability can provide credibility and may lower currency risk which may in turn encourage foreign participation and lead to greater domestic currency intermediation (Eichengreen and Luengnaruemitchai, 2004; Claessens et al., 2007). However, a priori a positive relationship between exchange rate volatility and LCBM development seems also plausible as stable exchange rates may increase the incentives to issue debt in foreign, rather than local currency. We measure exchange rate volatility by the 5-year rolling standard deviation of the change of the log of exchange rates. Data are from the IMF's International Financial Statistics.

As a final economic policy variable we include foreign exchange reserves, which are measured as a share of GDP. Ex ante, its relationship with LCBM development is ambiguous. The relationship may be positive because large foreign reserves provide an indication that the country is not prone to currency crisis, reassuring potential investors. It may, however, also be negative because countries with large foreign exchange reserves tend have current account surpluses, which means that they are building up net asset positions abroad. Since exported savings are not invested domestically, they are not invested in LCBMs. Data on foreign exchange reserves are from the IMF's International Financial Statistics.

The third group of explanatory variables we consider refers to the quality of institutions. We include a variable capturing the legal origin because there is some evidence that in countries whose legal rules originate in the British common law tradition as opposed to the civil law tradition financial markets are more developed, arguably because legal rules originating in the British common law tradition tend to offer a better protection to investors. ${ }^{12} \mathrm{We}$ construct a dummy variable capturing whether a country has a British legal origin or not.

There is considerable evidence from studies on other world regions that there is a positive relationship between the ability of the government to pursue policies that promote private-sector development and the rule of law on the one hand, and bond market development on the other (Eichengreen and Luengnaruemitchai, 2004; Burger and Warnock, 2006). ${ }^{13}$ We therefore include an additional variable, governance, which is a composite indicator based on two indices from the

\footnotetext{
${ }^{12}$ Key publications championing this 'legal origin view' are La Porta et al. (1998) and Beck et al. (2003). For evidence for a positive relationship between British legal origin and bond market development, see, for instance, Essers et al. (2015).

${ }^{13}$ See for instance Burger and Warnock (2006) and Eichengreen and Luengnaruemitchai (2004).
} 
Worldwide Governance Indicators dataset (Kaufmann et al., 2014), namely regulatory quality and rule of law. Regulatory quality captures perceptions of the ability of the government to formulate and implement sound policies and regulations that permit and promote private-sector development. Rule of law captures perceptions of the extent to which agents have confidence in and abide by the rules of society, and in particular the quality of contract enforcement, property rights, the police, and the courts, as well as the likelihood of crime and violence. The two components, regulatory quality and rule of law, have been weighted equally. Higher values of the index indicate better governance.

Finally, we include a variable capturing the openness of political institutions, polity2. There is a considerable body of research which argues that countries which have more open political institutions are likely to have more developed financial markets. ${ }^{14}$ Polity 2 measures regime types on a scale ranging from -0.1 (strongly autocratic) to +0.1 (strongly democratic). Data are taken from the Polity IV dataset (Marshall et al., 2014).

\section{(iv) Caveats}

While our model specifications build on existing studies on bond market development in developing and emerging economies, there remain some important methodological concerns. The most serious concern is in regard to the limited number of observations due to missing values. As Appendix Table A2, which presents the descriptive statistics for our dependent and explanatory variables, shows, our sample covers a maximum of 27 SSA countries and a maximum of 14 years, but due to missing values (and the use of a 1-year lag of the explanatory variables) the analysis that follows extends to no more than 248 observations. ${ }^{15}$ The limited number of observations limits both the power of statistical tests and the degree to which the results may be generalisable across SSA.

In addition, our models, the POLS with PCSE model and the RE model, do not address potential reverse causality and endogeneity beyond using lags of the explanatory variables. We would have liked to use a modelling approach which gives more weight to dynamics, for instance by incorporating a greater number of lags for the explanatory variables, or using an error correction

\footnotetext{
${ }^{14}$ An excellent overview is provided by Haber et al. (2008). Evidence for a positive relationship between democracy and bond market development is provided, for instance, by Claessens et al. (2007) and Essers et al. (2015).

15 Our dependent variable, for instance, is available for a maximum of 27 (countries) times 14 (years) minus 120 (missings), that is 258 observations.
} 
model. ${ }^{16}$ However, as outlined above, the most significant part of variation in our sample is cross-country rather than intertemporal variation, rendering the use of more dynamic approaches and the estimation of long- and short-term effects difficult. ${ }^{17}$ That said, we still think that the empirical analysis in this article helps to improve our understanding of LCBMs in SSA and complements existing studies because it relies on a novel, relatively large dataset with a focus on SSA, hence the ability to probe the robustness of the results of existing studies and compare our results with those relating to other world regions.

\section{(v) Results}

Figure A1 in the appendix consists of a series of scatterplots, showing correlations between the dependent variable, namely the stock of local currency treasury bonds, and the various lagged explanatory variables in 2012. Table A3 in the appendix shows the pair-wise correlations between stock of local currency treasury bonds, and the various lagged explanatory variables in 2012. We find: a significant, positive correlation between LCBM development and the natural $\log$ of GDP; a significant, positive correlation between LCBM development and the natural $\log$ of GDP per capita, which appears to be driven by Mauritius and South Africa; ${ }^{18}$ a positive correlation between LCBM development and trade openness; a significant, positive correlation between LCBM development and private credit by banks; a negative correlation between LCBM development and the resource rents in percentage of GDP; a negative correlation between LCBM development and past fiscal surpluses; a positive correlation between LCBM development and inflation rates, which appears to be driven by Kenya; ${ }^{19}$ a positive correlation between LCBM development and capital account openness; a positive correlation between LCBM development and exchange rate volatility; a positive correlation between foreign exchange reserves and LCBM development; a positive correlation between LCBM development and British legal origin; a significant, positive correlation between LCBM development and the quality of governance (the composite index capturing regulatory quality and the rule of law); a significant

\footnotetext{
${ }^{16}$ We experimented with specifications using contemporaneous values, one lag, and two lags of the explanatory variables. Except for the finding that trade openness is only significant in specifications with lagged explanatory variables, the results from specifications with these different lag structures are qualitatively similar.

${ }^{17}$ In many countries LCBM development only gained pace from about 2008 onwards, thus intertemporal variation in our sample is only prevalent in a very short time span of 6 years.

${ }^{18}$ If we exclude Mauritius and South Africa from the sample, the positive correlation loses significance.

${ }^{19}$ In 2010 and 2011 Kenya, which has deep financial markets, experienced high inflation rates. If we exclude Kenya from the sample, the slope of the fitted line is almost flat.
} 
positive correlation between LCBM development and the degree to which countries are democratic.

\section{(vi) Results of regression models}

Tables 5 and 6 show the estimation results of our regression models. The estimation results of the POLS with PCSE are presented in Table 5 and the estimation results of the RE model are presented in Table 6. While the estimation results for the two different models differ slightly, five variables seem to be quite robustly correlated with LCBM development.

First, countries with greater economic size, as measured by the natural log of GDP, seem to have more developed LCBMs. This result is in line with the findings of other studies such as $\mathrm{Mu}$ et al. (2013, p. 131), Eichengreen and Luengnaruemitchai (2004), and Claessens et al. (2007). ${ }^{20}$ Second, greater openness to trade appears to be associated with deeper LCBMs. Third, more developed banking sectors are positively correlated with LCBM development. Other studies, such as Eichengreen and Luengnaruemitchai (2004) and Essers et al. (2015), also present results that suggest that there is a significant and positive relationship between the size of the banking sector and trade openness on the one hand, and LCBM development on the other. The finding that countries with a more developed banking sector tend to be the ones with more developed bond markets is in line with the finding that commercial banks have, on balance, remained the dominant investor class in LCBMs in SSA (Essers et al., 2015). Fourth, there is a significant and negative relationship between foreign exchange reserves and the development of LCBMs. While this result appears to be counterintuitive at first, one possible explanation is that large foreign exchange reserves tend to be associated with current account surpluses, which means that a country is accumulating foreign assets, which may come at the expense of domestic investments into LCBMs. Fifth, governance is significantly and positively correlated with LCBM development. This finding is in line with the argument that a strong regulatory framework promotes financial deepening and with results by others such as Eichengreen and Luengnaruemitchai (2004) and Essers et al. (2015). In addition, capital account openness is positively correlated with LCBM development in most of our specifications, a finding that also emerges in the analysis of Eichengreen and Luengnaruemitchai (2004), which examines the

\footnotetext{
${ }^{20}$ The positive and significant relationship between economic size and the development of LCBMs is also the most robust result emerging from our additional analyses using FGLS and FE models to examine intertemporal variation. The results are presented in the online appendix.
} 
determinants of local currency government bond markets in developed and developing countries in various world regions.

As regards the remaining explanatory variables, the evidence of a significant relationship with LCBM development is less robust. Specifically, the results from the POLS with PCSE suggests that there is a negative relationship between LCBM development and fiscal deficits, but this result does not hold for the RE model. Countries with British legal origin appear to have less developed LCBMs than others, a finding that contradicts results from other studies such as the analysis of LCBMs in SSA by Essers et al. (2015), but has also been found by others, such as Eichengreen et al. (2008), who analyse LCBM with a focus on Latin America. There is some evidence that countries which are more democratic have more developed LCBMs, although this result only holds if we do not control for resource dependence. Finally, in two out of eight models there is some evidence that lower stages of economic development are associated with deeper LCBMs. ${ }^{21}$ While this finding is surprising, other studies of the determinants of LCBM development, for instance Essers et al. (2015) and Eichengreen and Luengnaruemitchai (2004), present similar results. One possible explanation is that governments in richer economies have a broader fiscal base which allows them to rely less on LCBM financing.

Table 7 summarizes the main results of the analyses presented above and provides a comparison with the findings of the study of the drivers of LCBM development in SSA by Essers et al. (2015) and of three studies which focus on other regions, namely Claessens et al. (2007), who examine the drivers of LCBM development in a global sample covering emerging and developed economies; Eichengreen and Luengnaruemitchai (2004), who examine the drivers of LCBM development using a global sample with a focus on Asia; and Eichengreen et al. (2008), who examine the drivers of domestic bond market development in Latin America. ${ }^{22}$ The picture that emerges is that in SSA, as in other world regions, there appear to be benefits for LCBM development if countries are larger in economic terms, if they have larger banking systems, if they are more open to trade, and if they have better regulatory frameworks and rule of law. In our empirical analysis, fiscal deficits are not as consistently negatively associated with local currency bond market development as was the case in some previous studies of LCBMs in Africa and elsewhere. Likewise, and perhaps surprisingly, macroeconomic stability as measured by inflation rates and exchange rate volatility does not come out as a significant factor in our

\footnotetext{
${ }^{21}$ As the table presented in the online appendix suggests, this finding is also supported by some of our additional analyses using feasible GLS and FE estimators.

${ }^{22}$ Our focus is on the results of the regression models where government bond market development is the dependent variable.
} 
analyses, while we find larger foreign exchange reserves to have a negative impact on LCBM development.

Table 5: POLS with PCSE

\begin{tabular}{|c|c|c|c|c|}
\hline & \multicolumn{4}{|c|}{ Bonds to GDP } \\
\hline & $(1)$ & (2) & (3) & (4) \\
\hline \multirow[t]{2}{*}{$\operatorname{Ln~GDP}_{t-1}$} & $0.0132 * * *$ & $0.0142 * * *$ & $0.0213 * * *$ & $0.0417 * * *$ \\
\hline & $(0.00180)$ & $(0.00326)$ & $(0.00454)$ & $(0.00592)$ \\
\hline \multirow[t]{2}{*}{ Ln GDP per capita t-1 $_{t}$} & 0.000446 & -0.00500 & -0.0193 & $-0.0412 * *$ \\
\hline & $(0.00595)$ & $(0.0117)$ & $(0.0123)$ & $(0.0131)$ \\
\hline \multirow[t]{2}{*}{ Trade to $\mathrm{GDP}_{t-1}$} & $-0.0601^{+}$ & 0.0465 & $0.127 * *$ & $0.175^{* *}$ \\
\hline & $(0.0356)$ & $(0.0377)$ & $(0.0432)$ & $(0.0664)$ \\
\hline \multirow{2}{*}{ Private credit to GDP ${ }_{t-1}$} & $0.353 * * *$ & $0.393 * * *$ & $0.344 * * *$ & $0.262 * * *$ \\
\hline & $(0.0270)$ & $(0.0418)$ & $(0.0430)$ & $(0.0575)$ \\
\hline \multirow[t]{2}{*}{ Fiscal balance to $\mathrm{GDP}_{t-1}$} & & $-0.407 * * *$ & $-0.388 * * *$ & $-0.316^{* *}$ \\
\hline & & $(0.103)$ & $(0.0997)$ & $(0.101)$ \\
\hline \multirow[t]{2}{*}{ Inflation rates $_{t-1}$} & & 0.0589 & 0.0404 & -0.0214 \\
\hline & & $(0.0772)$ & $(0.0735)$ & $(0.0918)$ \\
\hline \multirow{2}{*}{ Capital account openness ${ }_{t-}$} & & $0.971 * * *$ & $0.990 * * *$ & $1.280 * * *$ \\
\hline & & $(0.148)$ & $(0.150)$ & $(0.336)$ \\
\hline \multirow{2}{*}{ Exchange rate volatility $y_{t-1}$} & & -0.0652 & -0.0874 & -0.0773 \\
\hline & & $(0.0695)$ & $(0.0588)$ & $(0.0654)$ \\
\hline \multirow{2}{*}{$\begin{array}{l}\text { Foreign exchange reserves } \\
\text { to } \mathrm{GDP}_{t-1}\end{array}$} & & $-0.127 * *$ & $-0.147 * * *$ & $-0.189 * * *$ \\
\hline & & $(0.0420)$ & $(0.0363)$ & $(0.0400)$ \\
\hline \multirow[t]{2}{*}{ British legal origin } & & & -0.0165 & $-0.0471 * *$ \\
\hline & & & $(0.0119)$ & $(0.0177)$ \\
\hline \multirow[t]{2}{*}{ Polity $2_{t-1}$} & & & $0.194 * *$ & -0.121 \\
\hline & & & $(0.0724)$ & $(0.187)$ \\
\hline \multirow[t]{2}{*}{ Governance $_{t-1}$} & & & $0.0390 *$ & $0.105 * * *$ \\
\hline & & & $(0.0198)$ & $(0.0288)$ \\
\hline \multirow[t]{2}{*}{ Resource rents to $\mathrm{GDP}_{t-1}$} & & & & -0.0186 \\
\hline & & & & $(0.0430)$ \\
\hline \multirow[t]{2}{*}{ Constant } & $-0.303 * * *$ & $-0.309 * * *$ & $-0.368 * * *$ & $-0.614 * * *$ \\
\hline & $(0.0462)$ & $(0.0821)$ & $(0.0937)$ & $(0.0944)$ \\
\hline Observations & 248 & 130 & 130 & 96 \\
\hline$R^{2}$ & 0.7268 & 0.8039 & 0.8198 & 0.8166 \\
\hline$\chi^{2} \mathrm{p}$-value & 0.0000 & 0.0000 & 0.0000 & 0.0000 \\
\hline
\end{tabular}

Notes: Standard errors in parentheses. ${ }^{+} p<0.10,{ }^{*} p<0.05, * * p<0.01, * * * p<0.001$. 
Table 6: RE estimator

\begin{tabular}{|c|c|c|c|c|}
\hline & \multicolumn{4}{|c|}{ Bonds to GDP } \\
\hline & (1) & (2) & (3) & (4) \\
\hline \multirow[t]{2}{*}{$\operatorname{Ln} \mathrm{GDP}_{t-1}$} & $0.0156^{*}$ & $0.0139^{+}$ & $0.0218^{*}$ & $0.0417 * * *$ \\
\hline & $(0.00614)$ & $(0.00779)$ & $(0.0110)$ & $(0.00581)$ \\
\hline \multirow[t]{2}{*}{ Ln GDP per capita ${ }_{t-1}$} & -0.000330 & 0.00999 & -0.00652 & $-0.0412 * *$ \\
\hline & $(0.0100)$ & $(0.0222)$ & $(0.0192)$ & $(0.0138)$ \\
\hline \multirow[t]{2}{*}{ Trade to $\mathrm{GDP}_{t-1}$} & -0.0395 & 0.0526 & $0.129 * * *$ & $0.175 * * *$ \\
\hline & $(0.0482)$ & $(0.0466)$ & $(0.0366)$ & $(0.0507)$ \\
\hline \multirow{2}{*}{ Private credit to GDP ${ }_{t-1}$} & $0.355^{* * *}$ & $0.307 * * *$ & $0.215^{*}$ & $0.262 * *$ \\
\hline & $(0.0673)$ & $(0.0728)$ & $(0.0954)$ & $(0.0926)$ \\
\hline \multirow[t]{2}{*}{ Fiscal balance to $\mathrm{GDP}_{t-1}$} & & -0.378 & -0.399 & -0.316 \\
\hline & & $(0.253)$ & $(0.261)$ & $(0.279)$ \\
\hline \multirow[t]{2}{*}{ Inflation rates $_{t-1}$} & & -0.0503 & -0.0557 & -0.0214 \\
\hline & & $(0.0439)$ & $(0.0460)$ & $(0.0664)$ \\
\hline & & $0.968 *$ & 0.698 & $1.280 * * *$ \\
\hline openness $_{t-1}$ & & $(0.385)$ & $(0.604)$ & $(0.354)$ \\
\hline Exchange rate volatility $_{t-}$ & & -0.0668 & -0.0844 & -0.0773 \\
\hline 1 & & $(0.0493)$ & $(0.0537)$ & $(0.0728)$ \\
\hline Foreign exchange & & $-0.135 *$ & $-0.142 *$ & $-0.189 * *$ \\
\hline reserves to $\mathrm{GDP}_{t-1}$ & & $(0.0658)$ & $(0.0647)$ & $(0.0672)$ \\
\hline \multirow[t]{2}{*}{ British legal origin } & & & -0.0157 & $-0.0471 *$ \\
\hline & & & $(0.0213)$ & $(0.0208)$ \\
\hline \multirow[t]{2}{*}{ Polity $2_{t-1}$} & & & $0.240^{+}$ & -0.121 \\
\hline & & & $(0.124)$ & $(0.252)$ \\
\hline \multirow{2}{*}{ Governance $_{t-1}$} & & & $0.0577 *$ & $0.105 * *$ \\
\hline & & & $(0.0292)$ & $(0.0346)$ \\
\hline \multirow[t]{2}{*}{ Resource rents to $\mathrm{GDP}_{t-1}$} & & & & -0.0186 \\
\hline & & & & $(0.0505)$ \\
\hline \multirow[t]{2}{*}{ Constant } & $-0.361 * *$ & $-0.376^{*}$ & $-0.426^{+}$ & $-0.614 * * *$ \\
\hline & $(0.122)$ & $(0.165)$ & $(0.222)$ & $(0.150)$ \\
\hline Observations & 248 & 130 & 130 & 96 \\
\hline$R^{2}$ & 0.7246 & 0.7917 & 0.8013 & 0.8166 \\
\hline$\chi^{2} \mathrm{p}$-value & 0.0000 & 0.0000 & 0.0000 & 0.0000 \\
\hline
\end{tabular}

Notes: Robust standard errors in parentheses. ${ }^{+} p<0.10, * p<0.05, * * p<0.01, * * * p<0.001$. 
Table 7: Comparison of results

\begin{tabular}{|c|c|c|c|c|c|c|}
\hline \multirow[b]{2}{*}{ Model } & \multicolumn{2}{|c|}{ This paper } & \multicolumn{4}{|c|}{ Selected other studies } \\
\hline & $\begin{array}{l}\text { POLS with } \\
\text { PCSE }\end{array}$ & $\mathrm{RE}$ & $\begin{array}{c}\text { Eichengreen and } \\
\text { Luengnaruemitchai (2004) }\end{array}$ & Claessens et al. (2007) & $\begin{array}{c}\text { Eichengreen et al. } \\
\text { (2008) }\end{array}$ & Essers et al. (2015) \\
\hline Size of the economy (measured by GDP) & + & + & + & + & $\begin{array}{l}\text { GDP:+; } \\
\text { GDP }^{2}:-\end{array}$ & + \\
\hline Stage of economic development & & & - & n.a. & $\begin{array}{l}\text { GDPPC:+; } \\
\text { GDPPC }^{2}:-\end{array}$ & \\
\hline Trade openness & + & + & + & n.a. & + & + \\
\hline Size of the banking sector & + & + & + & + & & + \\
\hline Fiscal balance & - & & - & n.a. & - & - \\
\hline Inflation & & & n.a. & - & n.a. & - \\
\hline Capital account openness & + & & + & n.a. & - & \\
\hline Exchange rate volatility & & & - & n.a. & n.a. & \\
\hline Foreign exchange reserves & - & - & n.a. & n.a. & n.a. & n.a. \\
\hline British legal origin & & & + & n.a. & - & + \\
\hline Democracy & & & n.a. & + & n.a. & + \\
\hline Regulatory quality and/or rule of law & + & + & $\begin{array}{c}\text { Rule of law: }+ \\
\text { Bureaucracy quality: - }\end{array}$ & n.a. & & + \\
\hline Resource dependence & & & n.a. & n.a. & n.a. & \\
\hline
\end{tabular}

Notes: $+=$ relationship positive and significant; $-=$ relationship negative and significant. As regards results from the analysis presented in this paper, we only report a relationship as 'significant' in this table where results are significant in all more fully specified models, i.e. in all models which include besides other variables the variables relating to the quality of institutions (Polity2, governance, and British legal origin). n.a. = not applicable because not included in the analysis. 


\section{Lessons from emerging markets}

Since the emerging market crises of the late 1990s, many emerging markets have sought to develop LCBMs to reduce foreign currency debt and overcome the currency and maturity mismatch problems that had previously contributed to financial vulnerability. This strategy has been apparently quite successful (Turner, 2012) as markets in Latin America and Emerging Asia managed to significantly increase the share of bonds denominated in local currency (Table 8). LCBMs provided an important cushion during the Global Financial Crisis when US and European financial institutions struggled for survival and would no longer extend credit to emerging markets. ${ }^{23}$

Table 8: Currency denomination in bond markets by broad area

\begin{tabular}{|c|c|c|c|c|c|c|c|c|}
\hline & \multicolumn{2}{|c|}{2000} & \multicolumn{2}{|c|}{2005} & \multicolumn{2}{|c|}{2010} & \multicolumn{2}{|c|}{ 2011* } \\
\hline & $\begin{array}{c}\text { Local } \\
\text { currency }\end{array}$ & $\begin{array}{l}\text { Foreign } \\
\text { currency }\end{array}$ & $\begin{array}{l}\text { Local } \\
\text { currency }\end{array}$ & $\begin{array}{l}\text { Foreign } \\
\text { currency }\end{array}$ & $\begin{array}{c}\text { Local } \\
\text { currency }\end{array}$ & $\begin{array}{l}\text { Foreign } \\
\text { currency }\end{array}$ & $\begin{array}{c}\text { Local } \\
\text { currency }\end{array}$ & $\begin{array}{l}\text { Foreign } \\
\text { currency }\end{array}$ \\
\hline Euro area & 90.0 & 10.0 & 89.9 & 10.1 & 89.8 & 10.2 & 90.3 & 9.7 \\
\hline Japan & 98.5 & 1.5 & 99.1 & 0.9 & 99.4 & 0.6 & 99.4 & 0.6 \\
\hline $\begin{array}{l}\text { Latin } \\
\text { America }\end{array}$ & 46.0 & 54.0 & 59.9 & 40.1 & 71.2 & 28.8 & 70.8 & 29.2 \\
\hline $\begin{array}{l}\text { Emerging } \\
\text { Asia }\end{array}$ & 88.4 & 11.6 & 91.2 & 8.8 & 94.2 & 5.8 & 94.3 & 5.7 \\
\hline
\end{tabular}

Note: *End September 2011.

Source: Turner (2012).

Since experiences differ significantly across economies, both emerging and mature, it is difficult to pinpoint one single element of reform or practice that will help the emergence of a deep and liquid LCBM (Luengnaruemitchai and Ong, 2005). Broadly speaking, the experiences of emerging economies in Asia and Latin America confirm the importance of the variables that we found to be significant in our empirical analysis of the drivers and obstacles to LCBM development in SSA. ${ }^{24}$ However, it is important to point out that in both Latin American and Asian countries successes in LCBM development can be linked to concerted policy efforts at the national level, which have been supported by regional and international

\footnotetext{
${ }^{23}$ As pointed out by Citi Securities and Fund Services (2013, p. 3): 'The Asian [local currency] corporate bond market, which underwent significant changes in the aftermath of 1998 Asia financial crisis, acted as a cushion for corporate financing during the global crisis. The markets operated as a balancing-act against fluctuating sentiment in global markets as well as slowing banking credit.'

${ }^{24}$ Eichengreen and Luengnaruemitchai $(2004$, p. 1), for instance, find that '[1]arger country size, stronger institutions, less volatile exchange rates, and more competitive banking sectors tend to be positively associated with bond market capitalization' while 'Asian countries' strong fiscal balances, while admirable on other grounds, have not been conducive to the growth of government bond markets'.
} 
initiatives. Regional cooperation for LCBM development has been a decisive factor, particularly for the laggard markets of East Asia, where in 2002 the ASEAN+3 Finance Ministers launched the ASIAN+3 Bond Market Initiative (ABMI), ${ }^{25}$ under which a number of initiatives were developed aimed at improving the regulatory framework, facilitating bond issuance, and broadening the investor base. One example for an ABMI activity is the ASEAN+3 Bond Market Forum (ABMF), which was launched as a platform to promote standardization of market practices and harmonization of regulations relating to cross-border transactions across the region in 2010. Another example of regional cooperation is the Asian Bond Fund $(\mathrm{ABF})$ initiative, where a number of central banks invested parts of their reserves in the Pan Asia Bond Index Fund as well as eight country-specific index funds.

Although significant progress has been made, challenges remain in many of these markets, including low levels of liquidity, a narrow investor base, and short maturities. A particular problem has been the high share of foreign bond holdings in individual LCBMs. In Asia, this has at times caused problems in Indonesia and Malaysia, where foreign holdings make up more than a third of the local currency government bond market, but also Thailand, where foreign holdings account for close to 20 per cent (Figure 7). The latter gives a good illustration how a large foreign investor base can be problematic at times: fuelled by unconventional monetary policies in the major advanced economies, non-resident net holding in the Thai bond market increased very rapidly from Thai baht (THB) 66 billion in December 2009 to a peak of THB 870 billion in April 2013, the month before Fed Chairman Bernanke's 'tapering' announcement. In anticipation of rising US interest rates and a (temporary) current account deficit at the time, Thailand saw large capital outflows and a depreciation of the THB, leading to worries of a repeat of the Thai crisis of 1997. The situation stabilized again relatively quickly, but non-resident net holding in the Thai bond market continued to decline to THB 640 billion in May 2014. For Thailand, an upper middle-income economy with comparably developed financial markets, this episode was challenging but a crisis could be avoided. But for low-income economies with shallow financial markets, such as those in SSA, even relatively small capital outflows can have a seriously destabilizing effect on the exchange rate, financial markets, and the real economy. This is important to highlight at a time when several SSA economies have become 'frontier markets', experiencing large capital inflows, which may reverse again quickly due to domestic or international factors.

\footnotetext{
${ }^{25}$ ASEAN +3 comprises the 10 member countries of the Association of Asian Nations as well as China, Japan, and Korea.
} 
Figure 7: Foreign holdings in LCY government bonds (as \% of total)

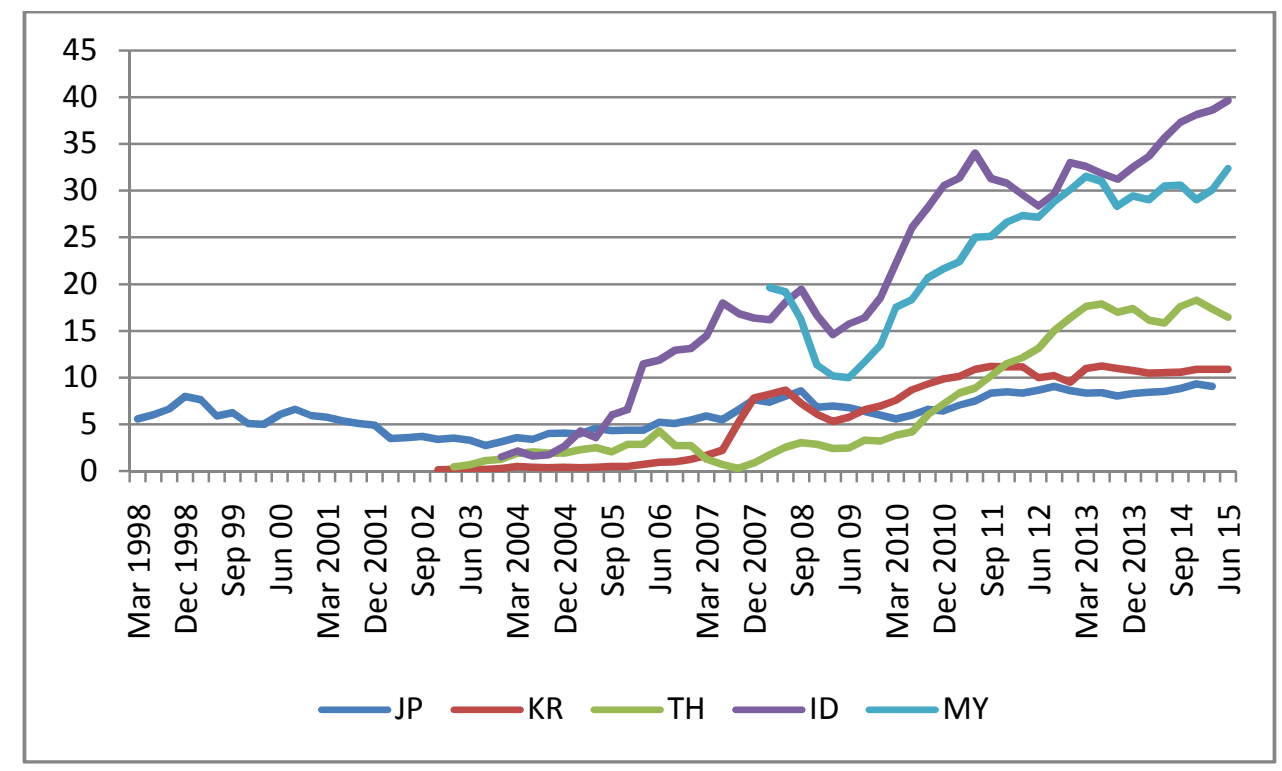

Source: Compiled by authors with data from ADB AsianBondsOnline.

While a greater participation of foreign investors may lower long-term government bond yields (Peris, 2010) and increase market liquidity, a high dependency on a foreign investor base increases the risk of sudden outflows and spillovers from global markets. As pointed out by Azis et al. (2013):

while the growth of individual bond markets in recent years has been impressive, the threat of financial contagion to emerging Asian bond markets from shock and volatility spillovers in mature markets is real. Although emerging Asian local bond market volatilities are more determined by their own respective shocks and volatilities, in some markets the direct shock and volatility spillovers remain significant.

Consequentially, broadening the investor base has been identified as a key challenge in further developing market resilience (ADB, 2013). In this context it should be emphasized that a high concentration of local sovereign bond holdings in the domestic banking system is equally dangerous, because sovereign debt problems can trigger a banking crisis and vice versa (as recently seen in Europe).

Moreover, in order to deal effectively with periods of rapid capital outflows, financial authorities need to develop tools for managing the capital account, which may also include the temporary re-imposition of capital controls (cf. IMF, 2012). 


\section{Conclusions and policy recommendations}

In this article we discussed the importance of LCBMs as a source of long-term financing for development and used a new dataset to investigate the factors that may help or inhibit LCBM development in SSA. Our empirical analysis of the relationship between a broad set of macroeconomic and institutional variables on the one side and LCBM development on the other pointed towards several factors that may be particularly important for LCBM development. Notably, we found greater economic size, larger banking sectors, greater openness to trade, and better regulatory quality and rule of law to be positively related to LCBM development. These findings are broadly in line with those of other studies on bond market development in SSA and other world regions.

A central challenge for developing LCBMs in SSA is to widen the investor base. Our analysis suggests that in SSA, countries with a more developed banking sector tend to be the ones with more developed LCBMs, which is in tune with the finding that commercial banks have, on balance, remained the dominant investor class in LCBMs in SSA. However, the dominance of banks among investors in LCBMs is problematic for several reasons. Since banks usually prefer a short-term portfolio allocation, it becomes more difficult for the government to issue longer maturities, which raises the rollover risk for the government (Bua et al., 2014). Moreover, a large exposure of domestic banks to domestic sovereign debt and a heavy reliance of governments on financing through domestic banks can cause mutually destabilizing effects when either the banks or the sovereign experiences a crisis.

From these empirical findings and the qualitative findings on the challenges of LCBM development in SSA we derive several policy recommendations. ${ }^{26}$ To overcome the problems associated with small economic size and small banking systems-including illiquid debt instruments, short maturities, a restricted and undifferentiated investor base, and undeveloped secondary markets-regional bond market development initiatives such as those initiated in Asia should be promoted in SSA, including initiatives for harmonizing legal and regulatory frameworks and for facilitating the cross-listing of bonds on several national exchanges.

To promote LCBM development, authorities in SSA should also address institutional and legal deficiencies to ensure the enforcement of laws and enhance the safety of the investment environment. This may include ensuring and alleviating profit repatriation, lowering payment delays, and guaranteeing contract viability. To overcome problems impeding the issuance of

\footnotetext{
${ }^{26}$ Some of these policy recommendations comply with those proposed by Adegelan and Radzweicz-Bak, (2009) and IMF et al. (2013).
} 
domestic debt it is important to establish an adequate infrastructure including the institutional structure and a solid legal framework. For better monitoring of domestic sovereign debt an appropriate debt management strategy needs to be put in place. It is also important to train personnel in the field of debt management adequately because these skills are needed for issuing domestic securities.

In the area of debt management, donors can be helpful in providing technical assistance. Programmes and initiatives like the World Bank's and the IMF's Debt Management Facility for Low-Income Countries and the Debt Management and Financial Analysis System of the United Nations Conference on Trade and Development (UNCTAD) provide country-specific technical assistance at different levels that broadly covers low-income countries. ${ }^{27}$ While donors can support the governments of low-income countries in defining and sequencing reforms, countries must institute the reforms themselves (Berensmann, 2015). Clearly, the sequencing and intensity of these policy measures will depend on the stage of the LCBM development as well as on the role that is envisaged for LCBMs in the respective countries. As pointed out, foreign investor participation broadens the investor base and can give a boost to market development, yet it may also increase volatility of international capital flows. Hence, capital market liberalization should be pursued only very cautiously and in pace with solid financial and institutional development.

Despite the various challenges for LCBM development in SSA and associated risks, they can become an important source for providing long- or medium-term capital not only for governments but also for companies. Although the development of local currency sovereign debt markets may theoretically divert investment away from private entrepreneurial activity, the emergence of a liquid yield curve for government securities is a crucial precondition for the development of an efficient corporate bond market. By releasing long-term funds for much-needed public infrastructure financing as well as facilitating corporate investment, the development of sovereign and corporate debt markets can make important contributions to sustainable development in SSA.

\footnotetext{
${ }^{27}$ A similar initiative is the World Bank Group's Global Emerging Markets Local Currency Bond Program (Gemloc), which supports LCBM development in emerging market countries (EMCs) (World Bank and IFC, 2015). One main drawback of this programme is that it focuses on EMCs rather than on low-income countries. For this reason only three SSA countries have been supported by this initiative: South Africa, Nigeria, and Kenya.
} 


\section{References}

Abbas, A. S. M., and Christensen, J. (2010), 'The Role of Domestic Debt Markets in Economic Growth: An Empirical Investigation for Low-income Countries and Emerging Markets', IMF Staff Papers 57(1), 209-55.

ADB (2013), 'Broadening the Investor Base for Local Currency Bonds in ASEAN+2 Countries', Manila, Asian Development Bank.

Adelegan, O. J., and Radzewicz-Bak, B. (2009), 'What Determines Bond Market Development in Sub-Saharan Africa?', Working Paper No. 09/213, Washington, DC, International Monetary Fund.

Arnone, M., and Presbitero, A. F. (2010), Debt Relief Initiative: Policy Design and Outcomes, Farnham, Ashgate Publishing.

Azis, I., Sabyasachi, J., Mitra, A. B., and Roselle, D. (2013), 'The Threat of Financial Contagion to Emerging Asia's Local Bond Markets: Spillovers from Global Crises', ADB Working Paper on Regional Economic Integration No. 106, Manila, Asian Development Bank.

AfDB (2014), 'African Financial Markets Database', Tunis, African Development Bank.

Beck, T. (2011), 'Finance and Oil. Is There a Resource Curse in Financial Development?', Tilburg, CentER and European Banking Center.

Beck, T., Demirgüç-Kunt, A., and Levine, R. (2003), 'Law and Finance: Why Does Legal Origin Matter?', Journal of Comparative Economics, 31(4), 653-75.

Berensmann, K. (2010), 'How to Prevent and Resolve Debt Crises in LICs?', DIE Discussion Paper 1/2010, Bonn, German Development Institute.

- (2015), 'Strengthening Low-Income Countries' Debt Management Capabilities to Better Weather Future Crises', forthcoming as DIE Discussion Paper, Bonn, German Development Institute.

Bua, G., Pradelli, J., and Presbitero, A. F. (2014), 'Domestic Public Debt in Low-income Countries: Trends and Structure', Review of Development Finance, 4(1), 1-19.

Burger, J. D., and Warnock, F. E. (2006), 'Local Currency Bond Markets', NBER Working Paper 12552, Cambridge, MA, National Bureau of Economic Research.

Calderón, C., and Liu, L. (2003), 'The Direction of Causality between Financial Development and Economic Growth', Journal of Development Economics, 72(1), 321-34.

Citi Securities and Fund Services (2013), 'Market Infrastructure Developments Impacting Asian Bond Markets', Citibank, April.

Claessens, S., Klingebiel, D., and Schmukler, S. L. (2007), 'Government Bonds in Domestic and Foreign Currency: The Role of Institutional and Macroeconomic Factors', Review of International Economics, 15(2), 370-413.

Dittmar, R. F., and Yuan, K. (2008), 'Do Sovereign Bonds Benefit Corporate Bonds in Emerging Markets?', Review of Financial Studies, 21(5), 1983-2014.

Eichengreen, B. and Hausmann, R. (1999), 'Exchange Rates and Financial Fragility', NBER Working Paper No. 7418, Cambridge, MA, National Bureau of Economic Research.

Eichengreen, B., and Luengnaruemitchai, P. (2004), 'Why Doesn't Asia Have Bigger Bond Markets?', NBER Working Paper No. 10576, Cambridge, MA, National Bureau of Economic Research. 
Eichengreen, B. J., Panizza, U., and Borensztein, E. (2008), 'Prospects for Latin American Bond Markets: A Cross-Country View', in E. Borensztein, K. Cowan, B. J. Eichengreen, and U. Panizza (eds), Bond Markets in Latin America: On the Verge of a Big Bang?, Cambridge, MA, MIT Press.

Essers, D., Blommestein, H., Cassimon, D., and Flores, P .I. (2015), 'Local Currency Bond Market Development in Sub-Saharan Africa: A Stock-Taking Exercise and Analysis of Key Drivers', Emerging Markets Finance and Trade, forthcoming.

Forslund, K., Lima, L., and Panizza, U. (2011), 'The Determinants of the Composition of Public Debt in Developing and Emerging Market Countries', Review of Development Finance, 1(3-4), 207-22.

Gros, D. (2013), 'Banking Union with a Sovereign Virus. The Self-serving Treatment of Sovereign Debt', Intereconomics, 48(2), 93-7.

Haber, S., North, D. C., and Weingast, B. R. (eds) (2008), Political Institutions and Financial Development, Stanford, CA, Stanford University Press.

Hausmann, R., and Panizza, U. (2003), 'On the Determinants of Original Sin: An Empirical Investigation', Journal of International Money and Finance, 22(7), 957-90.

Ito, H., and Chinn, M. D. (2008), 'A New Measure of Financial Openness', Journal of Comparative Policy Analysis, 10(3), 309-22.

Ito, H., and Chinn, M. D. (2014), 'Chinn-Ito Financial Openness Index', available at http://web.pdx.edu/ ito/Chinn-Ito_website.htm (accessed 10 July 2015).

IMF (2007), 'Regional Economic Outlook-Sub-Saharan Africa', World Economic and Financial Surveys, April, Washington, DC, International Monetary Fund.

- (2012), 'The Liberalization and Management of Capital Flows-An Institutional View', November, Washington, DC, International Monetary Fund.

(2013), 'Regional Economic Outlook: Sub-Saharan Africa: Building Momentum in a Multi-Speed World', World Economic and Financial Surveys, May, Washington, DC, International Monetary Fund.

- (2014), 'Regional Economic Outlook: Sub-Saharan Africa: Staying the Course', World Economic and Financial Surveys, October, Washington, DC, International Monetary Fund.

- (2015), 'West African Economic and Monetary Union. Common Policies of Member Countries-Staff Report; Press Release; and Statement by the Executive Director', IMF Country Report No. 15/100, April, Washington, DC, International Monetary Fund.

- World Bank, EBRD, and OECD (2013), 'Local Currency Bond Markets-a Diagnostic Framework', 9 July, Washington, DC, International Monetary Fund.

Khan, B. (2005), “'Original Sin” and Bond Market Development in Sub-Saharan Africa', in J. J. Teunissen and A. Akkerman (eds), Africa in the World Economy: The National, Regional and International Challenges, The Hague, FONDAD, 67-87.

Kaufmann, D., Kraay, A., and Mastruzzi, M. (2014), 'The Worldwide Governance Indicators', available at http://info.worldbank.org/governance/wgi/index.aspx\#home (accessed 10 July 2015), Washington, DC, World Bank.. 
La Porta, R., Lopez-de-Silanes, F., Shleifer, A., and Vishny, R.W. (1998), 'Law and Finance', The Journal of Political Economy, 106(6), 1113-55.

Luengnaruemitchai, P., and Ong, L. L. (2005), 'An Anatomy of Corporate Bond Markets: Growing Pains and Knowledge Gains', IMF Working Paper No. 05/152, Washington, DC, International Monetary Fund.

Marshall, M. G., Gurr, T. R., and Jaggers, K. (2014), 'Polity IV Project, Political Regime Characteristics and Transitions', availabe at http://www.systemicpeace.org/polity/polity4.htm (accessed 10 July 2015), Vienna, Center for Systemic Peace and Societal-Systems Research.

Maziad, A. A.-H., Pedras, G., Togo, E., Garcia-Kilroy, C., Jonasson, T., Loladze, T., Tsubota, H., and Blommestein, H. J. (2013), 'Local Currency Bond Markets-a Diagnostic Framework', Washington, DC, London, Paris, IMF, World Bank, EBRD, OECD.

Mbeng Mezui, C. A. (2012), 'Accessing Local Markets for Infrastructure: Lessons for Africa', ADB Working Paper No. 153, Tunis, African Development Bank.

Mu, Y., Phelps, P., and Stotsky, J. G. (2013), 'Bond Markets in Africa', Review of Development Finance, 3(3), 121-35.

OECD (2013), African Central Government Debt: Statistical Yearbook, Paris, Organization for Economic Cooperation and Development.

Peris, S. J. (2010), 'Foreign Participation in Emerging Markets' Local Currency Bond Markets', IMF Working Paper No. 10/88, Washington, DC, International Monetary Fund.

Rajan, R. G., and Zingales, L. (2003), 'The Great Reversals: The Politics of Financial Development in the Twentieth Century', Journal of Financial Economics, 69(1), 550.

Sy, A. N. R. (2007), 'Local Currency Debt Markets in the West African Economic and Monetary Union', IMF Working Paper No. 07/256, Washington, DC, International Monetary Fund.

Turner, P. (2012), 'Weathering Financial Crisis: Domestic Bond Markets in EMEs', BIS Paper No. 63, in Weathering Financial Crisis: Bond Markets in Asia and the Pacific, Basel, Bank for International Settlements.

Waygood, S. (2014), 'A Roadmap for Sustainable Capital Markets: How Can the UN Sustainable Development Goals Harness the Global Capital Markets?', Aviva White Paper, London, Aviva.

World Bank (2013), Financing for Development Post-2015, Washington, DC, World Bank, October.

- (2014), 'World Development Indicators', availableat http://data.worldbank.org/datacatalog/world-development-indicators (accessed 10 July 2015), Washington, DC, World Bank.

World Bank and IFC (2015), Developing Government Bond Markets Worldwide, Washington, DC, World Bank and International Finance Corporation. 
Figure A1: Bivariate scatter plots: local currency treasury bonds outstanding (\% of GDP) versus lagged explanatory variables*
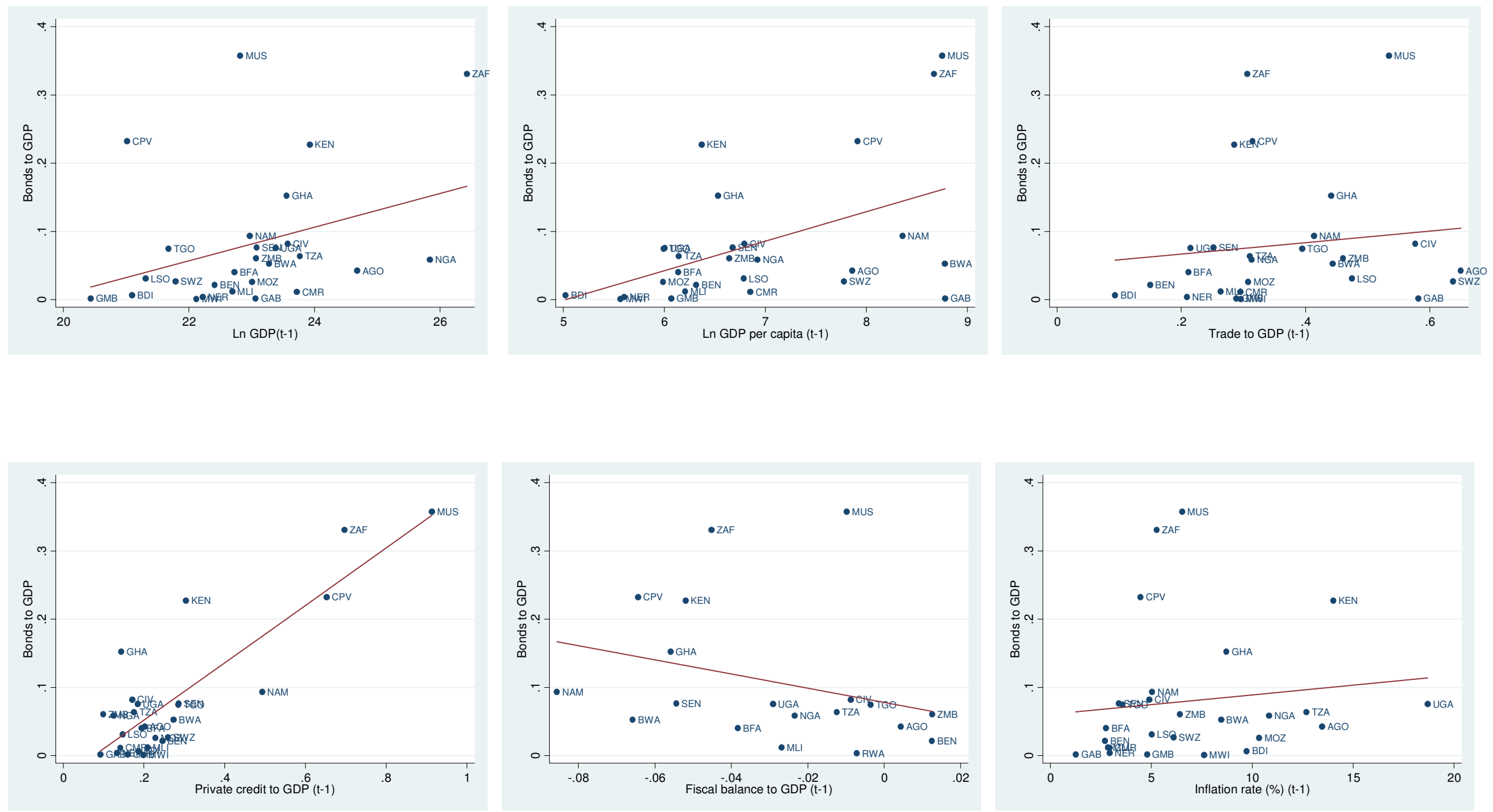

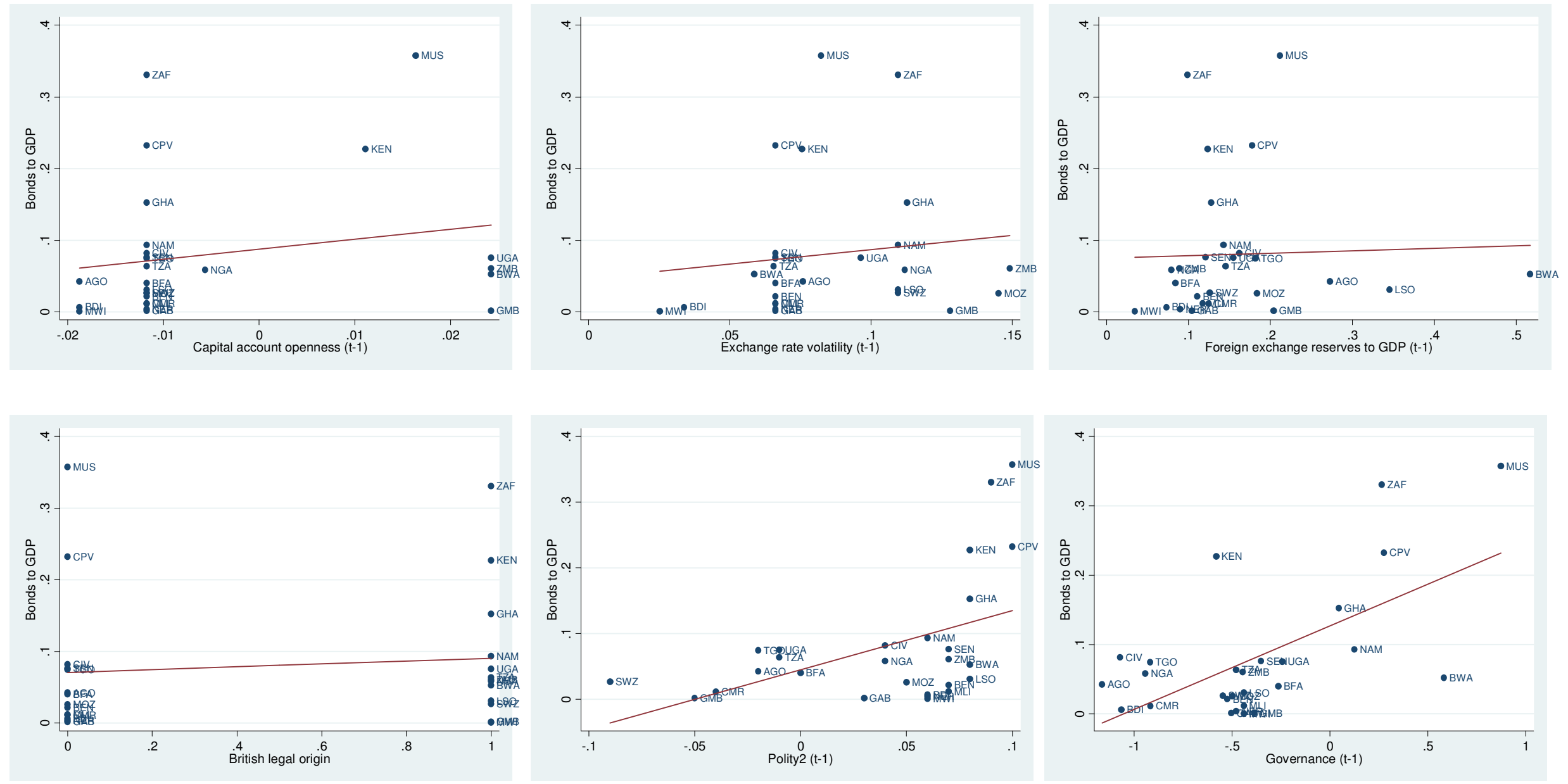

Note: ${ }^{*}$ Line represents fitted values. 


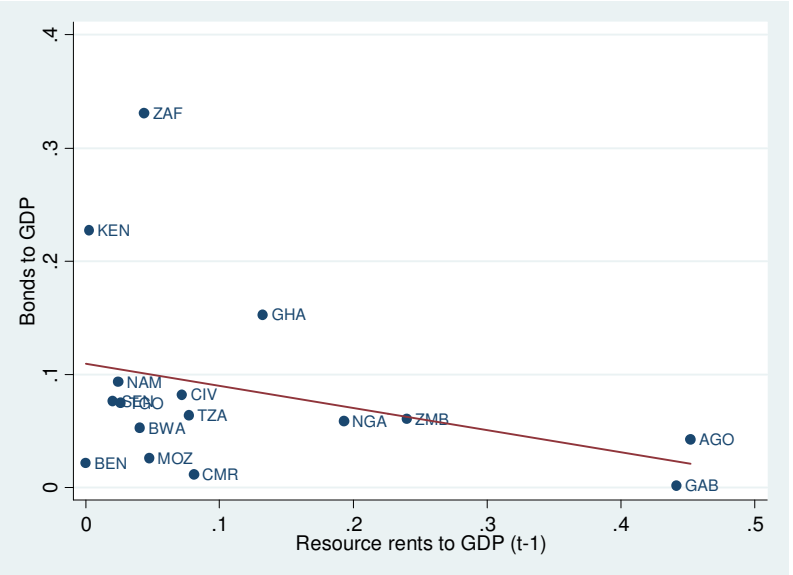


Table A1: Maximum coverage of the empirical analysis in selected studies

\begin{tabular}{|c|c|c|c|}
\hline Authors & $\begin{array}{l}\text { Maximum } \\
\text { coverage }\end{array}$ & Maximum coverage of African countries & $\begin{array}{l}\text { Type of public debt focused on in the } \\
\text { study }\end{array}$ \\
\hline This study & $\begin{array}{l}28 \text { countries in } \\
\text { SSA in the period } \\
2000-13\end{array}$ & $\begin{array}{l}\text { Angola, Benin, Botswana, Burkina Faso, Burundi, Cabo Verde, } \\
\text { Cameroon, Côte d'Ivoire, Gabon, The Gambia, Ghana, Kenya, } \\
\text { Lesotho, Malawi, Mali, Mauritius, Mozambique, Namibia, } \\
\text { Niger, Nigeria, Senegal, South Africa, Swaziland, Tanzania, } \\
\text { Togo, Uganda, Zambia }\end{array}$ & $\begin{array}{l}\text { Medium- and long-term (maturity of } 1 \\
\text { year or more) sovereign bonds in local } \\
\text { currency outstanding }\end{array}$ \\
\hline Essers et al. (2015) & $\begin{array}{l}15 \text { countries in } \\
\text { SSA in the period } \\
2003-12\end{array}$ & $\begin{array}{l}\text { Angola, Cameroon, Gabon, Kenya, Madagascar, Malawi, } \\
\text { Mauritius, Mozambique, Namibia, Nigeria, Sierra Leone, South } \\
\text { Africa, Tanzania, Uganda, Zambia }\end{array}$ & $\begin{array}{l}\text { Year-end outstanding marketable central } \\
\text { government debt in or indexed to local } \\
\text { currency }\end{array}$ \\
\hline $\begin{array}{l}\text { Eichengreen and } \\
\text { Luengnaruemitchai } \\
(2004)\end{array}$ & $\begin{array}{l}\text { 41countries in the } \\
\text { period } 1990-2001\end{array}$ & South Africa & $\begin{array}{l}\text { Domestic currency bonds issued by } \\
\text { residents (public and private sector) and } \\
\text { targeted to local investors }\end{array}$ \\
\hline $\begin{array}{l}\text { Claessens et al. } \\
\text { (2007) }\end{array}$ & $\begin{array}{l}35 \text { countries in the } \\
\text { period } 1993-2000\end{array}$ & South Africa & $\begin{array}{l}\text { Amounts outstanding of bonds } \\
\text { (including long-term bonds, notes, } \\
\text { Treasury bills, and money-market } \\
\text { instruments) issued by the public sector } \\
\text { (including all government levels and } \\
\text { state agencies) denominated in their } \\
\text { own local currency at year-end values. }\end{array}$ \\
\hline Bua et al. (2014) & $\begin{array}{l}40 \text { low-income and } \\
\text { lower middle- } \\
\text { income countries in } \\
\text { the period } 1971- \\
2011\end{array}$ & $\begin{array}{l}\text { Burundi, Benin, Burkina Faso, Central African Republic, } \\
\text { Comoros, Democratic Republic of Congo, Eritrea, Ethiopia, } \\
\text { Ghana, Guinea, The Gambia, Guinea Bissau, Kenya, Liberia, } \\
\text { Madagascar, Mali, Mozambique, Mauritania, Malawi, Niger, } \\
\text { Rwanda, Senegal, Sierra Leone, Chad, Togo, Tanzania, } \\
\text { Uganda, Zambia, Zimbabwe }\end{array}$ & $\begin{array}{l}\text { Domestic debt, defined as central } \\
\text { government debt owed to creditor } \\
\text { resident in the same country and } \\
\text { including all domestic financial } \\
\text { liabilities defined by the Government } \\
\text { Finance Statistics Manual (GFSM) } \\
\text { prepared by the IMF, with the exception } \\
\text { of arrears }\end{array}$ \\
\hline
\end{tabular}


Table A2: Summary statistics

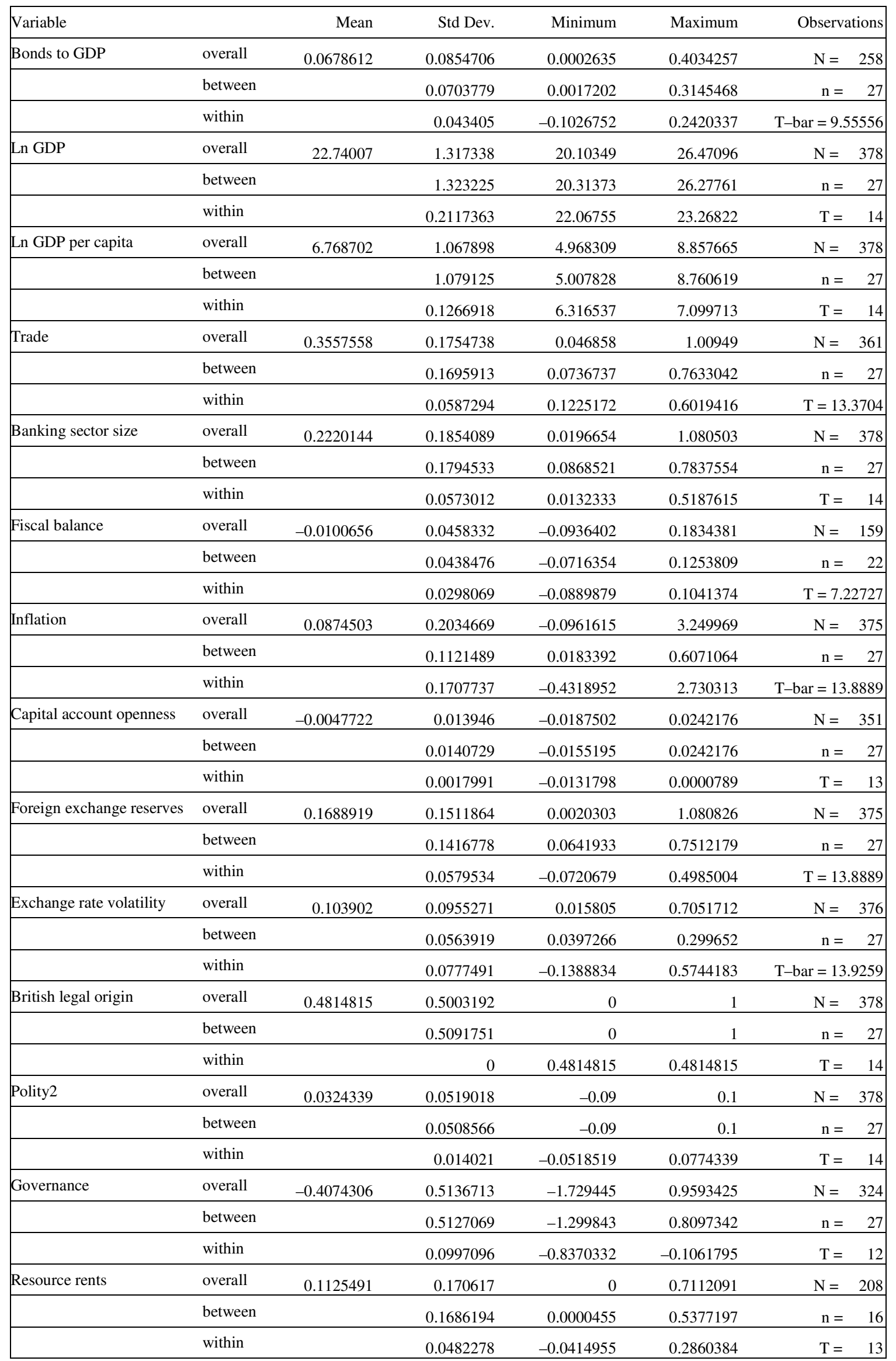


Table A3: Pair-wise correlations for the year 2012

\begin{tabular}{|c|c|}
\hline & Bond GDP \\
\hline Ln GDP $\operatorname{GD}_{t-1}$ & $\begin{array}{l}0.3431 * \\
(0.0798)\end{array}$ \\
\hline 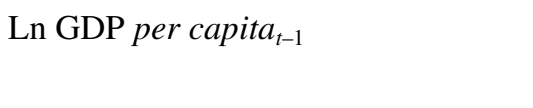 & $\begin{array}{l}0.4874 * \\
(0.0099)\end{array}$ \\
\hline Trade to $\mathrm{GDP}_{t-1}$ & $\begin{array}{l}0.1277 \\
(0.5255)\end{array}$ \\
\hline Private credit to $\mathrm{GDP}_{t-1}$ & $\begin{array}{l}0.8520 * \\
(0.0000)\end{array}$ \\
\hline Resource rents to $\mathrm{GDP}_{t-1}$ & $\begin{array}{l}-0.3288 \\
(0.2137)\end{array}$ \\
\hline Fiscal balance to $\mathrm{GDP}_{t-1}$ & $\begin{array}{l}-0.2546 \\
(0.3079)\end{array}$ \\
\hline Inflation rates $_{t-1}$ & $\begin{array}{l}0.1245 \\
(0.5363)\end{array}$ \\
\hline Capital account openness $s_{t-1}$ & $\begin{array}{l}0.2094 \\
(0.2945)\end{array}$ \\
\hline Exchange rate volatility ${ }_{t-1}$ & (0.5289) \\
\hline Foreign exchange reserves to $\mathrm{GDP}_{t-1}$ & $\begin{array}{l}0.0339 \\
(0.8668)\end{array}$ \\
\hline British legal origin & $\begin{array}{l}0.1034 \\
(0.6078)\end{array}$ \\
\hline Governance $_{t-1}$ & $\begin{array}{l}0.6146 * \\
(0.0006)\end{array}$ \\
\hline Polity $2_{t-1}$ & $\begin{array}{l}0.4704 * \\
(0.0133)\end{array}$ \\
\hline
\end{tabular}

Notes: P-values in parentheses. ${ }^{*} p<0.10$. 
Online Appendix Table 1: Patterns of LCBM development: Feasible GLS, Fixed Effects, and AR1 error model

\begin{tabular}{|c|c|c|c|c|c|c|c|c|c|c|c|c|}
\hline & \multicolumn{12}{|c|}{ Bonds to GDP } \\
\hline & \multicolumn{4}{|c|}{ FGLS } & \multicolumn{4}{|c|}{$\mathrm{FE}$} & \multicolumn{4}{|c|}{ AR1 error model } \\
\hline & (1) & (2) & (3) & (4) & (5) & (6) & (7) & $(8)$ & (9) & $(10)$ & (11) & (12) \\
\hline \multirow[t]{2}{*}{$\overline{\mathrm{Ln} \mathrm{GDP}_{t-1}}$} & $0.0142 * * *$ & $0.0164 * * *$ & $0.0177 * *$ & $0.0317 * * *$ & -0.239 & 0.501 & 0.476 & $1.133^{*}$ & $0.107 * *$ & $0.401 * * *$ & $0.376^{* * *}$ & $0.582 * * *$ \\
\hline & $(0.00202)$ & $(0.00281)$ & $(0.00630)$ & $(0.00669)$ & $(0.273)$ & $(0.312)$ & $(0.314)$ & $(0.400)$ & $(0.0396)$ & $(0.0824)$ & $(0.0776)$ & $(0.108)$ \\
\hline \multirow[t]{2}{*}{ Ln GDP per capita $_{t-1}$} & $-0.00425^{+}$ & -0.0117 & 0.00960 & $-0.0261 * *$ & 0.229 & $-0.735^{+}$ & -0.705 & $-1.430^{*}$ & -0.0546 & $-0.527 * * *$ & $-0.507 * * *$ & $-0.796 * * *$ \\
\hline & $(0.00256)$ & $(0.00729)$ & $(0.0117)$ & $(0.00882)$ & $(0.289)$ & $(0.424)$ & $(0.424)$ & $(0.546)$ & $(0.0574)$ & $(0.140)$ & $(0.132)$ & $(0.169)$ \\
\hline \multirow[t]{2}{*}{ Trade to $\mathrm{GDP}_{t-1}$} & -0.0113 & $0.0487^{+}$ & $0.110 * * *$ & $0.105^{* *}$ & -0.0637 & 0.0556 & 0.0653 & $0.179^{+}$ & -0.0219 & 0.0363 & 0.0487 & 0.0477 \\
\hline & $(0.0146)$ & $(0.0284)$ & $(0.0270)$ & $(0.0382)$ & $(0.0657)$ & $(0.0707)$ & $(0.0675)$ & $(0.0966)$ & $(0.0387)$ & $(0.0473)$ & $(0.0468)$ & $(0.0708)$ \\
\hline \multirow{2}{*}{ Private credit to $\mathrm{GDP}_{t-1}$} & $0.239 * * *$ & $0.399 * * *$ & $0.159 * * *$ & $0.159 * * *$ & 0.165 & -0.0800 & -0.0839 & -0.137 & $0.166^{*}$ & -0.0244 & -0.0304 & -0.119 \\
\hline & $(0.0221)$ & $(0.0182)$ & $(0.0309)$ & $(0.0387)$ & $(0.160)$ & $(0.147)$ & $(0.148)$ & $(0.176)$ & $(0.0717)$ & $(0.0592)$ & $(0.0568)$ & $(0.0807)$ \\
\hline \multirow[t]{2}{*}{ Fiscal balance to $\mathrm{GDP}_{t-1}$} & & $-0.113^{*}$ & $-0.168 * *$ & -0.0978 & & -0.264 & $-0.305^{+}$ & -0.349 & & -0.0918 & -0.129 & -0.109 \\
\hline & & $(0.0511)$ & $(0.0545)$ & $(0.0634)$ & & $(0.190)$ & $(0.174)$ & $(0.224)$ & & $(0.0937)$ & $(0.0858)$ & $(0.0806)$ \\
\hline \multirow[t]{2}{*}{ Inflation rates ${ }_{t-1}$} & & -0.0305 & -0.0174 & -0.0175 & & $-0.202 *$ & $-0.187^{*}$ & $-0.186^{+}$ & & -0.0540 & -0.0413 & -0.0392 \\
\hline & & $(0.0275)$ & $(0.0267)$ & $(0.0346)$ & & $(0.0741)$ & $(0.0746)$ & $(0.103)$ & & $(0.0525)$ & $(0.0518)$ & $(0.0584)$ \\
\hline \multirow{2}{*}{$\begin{array}{l}\text { Capital account } \\
\text { openness }\end{array}$} & & $1.092 * * *$ & $0.464^{+}$ & 0.557 & & -5.040 & -5.230 & -3.613 & & -1.057 & -1.272 & -3.473 \\
\hline & & $(0.149)$ & $(0.267)$ & $(0.363)$ & & $(6.767)$ & $(6.423)$ & $(6.787)$ & & $(2.328)$ & $(2.294)$ & $(2.889)$ \\
\hline \multirow[t]{2}{*}{ Exchange rate volatility $t_{t-1}$} & & -0.0465 & $-0.126 * * *$ & $-0.0892 *$ & & -0.0363 & -0.0446 & -0.148 & & -0.0696 & -0.0669 & -0.0576 \\
\hline & & $(0.0413)$ & $(0.0361)$ & $(0.0358)$ & & $(0.133)$ & $(0.141)$ & $(0.129)$ & & $(0.0718)$ & $(0.0700)$ & $(0.0716)$ \\
\hline Foreign exchange & & $-0.0876^{* *}$ & $-0.0847 * *$ & $-0.151 * * *$ & & -0.0355 & -0.0390 & -0.0762 & & -0.0317 & -0.0327 & -0.00942 \\
\hline reserves to $\mathrm{GDP}_{t-1}$ & & $(0.0308)$ & $(0.0317)$ & $(0.0388)$ & & $(0.0759)$ & $(0.0778)$ & $(0.0760)$ & & $(0.0436)$ & $(0.0422)$ & $(0.0461)$ \\
\hline British legal origin & & & $\begin{array}{l}-0.0168 \\
(0.0142)\end{array}$ & $\begin{array}{c}-0.0427^{*} \\
(0.0193)\end{array}$ & & & & & & & & \\
\hline \multirow[t]{2}{*}{ Polity $2_{t-1}$} & & & 0.0214 & 0.0278 & & & 0.384 & -0.170 & & & $0.327 *$ & -0.0281 \\
\hline & & & $(0.0779)$ & $(0.103)$ & & & $(0.396)$ & $(0.935)$ & & & $(0.155)$ & $(0.350)$ \\
\hline \multirow[t]{2}{*}{ Governance $_{t-1}$} & & & $0.0958 * * *$ & $0.101 * * *$ & & & 0.0322 & -0.0277 & & & 0.0627 & 0.0518 \\
\hline & & & $(0.0123)$ & $(0.0207)$ & & & $(0.0743)$ & $(0.0869)$ & & & $(0.0416)$ & $(0.0519)$ \\
\hline Resource rents to $\mathrm{GDP}_{t-1}$ & & & & -0.000474 & & & & 0.0228 & & & & 0.0406 \\
\hline Constant & $\begin{array}{c}-0.298 * * * \\
(0.0482)\end{array}$ & $\begin{array}{c}-0.312 * * * \\
(0.0515)\end{array}$ & $\begin{array}{c}-0.394 * * * \\
(0.0952)\end{array}$ & $\begin{array}{c}-0.453^{* * *} \\
(0.117)\end{array}$ & $\begin{array}{c}3.885 \\
(4.313)\end{array}$ & $\begin{array}{l}-6.532 \\
(4.470)\end{array}$ & $\begin{array}{l}-6.137 \\
(4.536)\end{array}$ & $\begin{array}{c}-16.62 * \\
(5.822)\end{array}$ & $\begin{array}{c}-2.173 * * * \\
(0.585)\end{array}$ & $\begin{array}{c}-5.709 * * * \\
(1.019)\end{array}$ & $\begin{array}{c}-5.181 * * * \\
(0.980)\end{array}$ & $\begin{array}{c}8.064 * * * \\
(1.466)\end{array}$ \\
\hline Observations & 248 & 128 & 128 & 95 & 248 & 130 & 130 & 96 & 248 & 130 & 130 & 96 \\
\hline$R^{2}$ & & & & & & & & & 0.7287 & 0.8654 & 0.8677 & 0.8498 \\
\hline$\chi^{2} \mathrm{p}$-value & 0.0000 & 0.0000 & 0.0000 & 0.0000 & & . & . & . & 0.0000 & 0.0000 & 0.0000 & 0.0000 \\
\hline Country FE & & & & & Yes & Yes & Yes & Yes & Yes & Yes & Yes & Yes \\
\hline Year FE & & & & & Yes & Yes & Yes & Yes & No & No & No & No \\
\hline
\end{tabular}

